\title{
Seaweeds: An Extensive Review of Medicinal Values
}

\section{Abdul Kader Mohiuddin*}

Secretary \& Treasurer Dr M. Nasirullah Memorial Trust, Tejgaon, Dhaka, Bangladesh

*Corresponding author: Abdul Kader Mohiuddin, Secretary \& Treasurer Dr M Nasirullah Memorial Trust, Tejgaon, Dhaka, Bangladesh, Tel: +8802-9110553; Email: trymohi@gmail.com

\section{Review Article \\ Volume 4 Issue 4}

Received Date: September 02, 2019

Published Date: October 17, 2019

DOI: $10.23880 /$ apct- 16000169

\section{Abstract}

The global economic impact of the five leading chronic diseases - cancer, diabetes, mental illness, CVD, and respiratory disease-could reach $\$ 47$ trillion over the next 20 years, according to a study by the World Economic Forum (WEF). According to the WHO, $80 \%$ of the world's population primarily those of developing countries rely on plant-derived medicines for the healthcare. The purported efficacies of seaweed derived phytochemicals showing great potential in obesity, T2DM, metabolic syndrome, CVD, IBD, sexual dysfunction and some cancers. Therefore, WHO, UN-FAO, UNICEF and governments have shown a growing interest in this unconventional food with health-promoting effects. Edible marine macro-algae (seaweed) are of interest because of their value in nutrition and medicine. Seaweeds contain several bioactive substances like polysaccharides, proteins, lipids, polyphenols, and pigments, all of which may have beneficial health properties. People consume seaweed as food in various forms: raw as salad and vegetable, pickle with sauce or with vinegar, relish or sweetened jellies and also cooked for vegetable soup. By cultivating seaweed, coastal people are getting an alternative livelihood as well as advancing their lives. In 2005, world seaweed production was totaled 14.7 million tons which more than double (30.4 million tons) in 2015. The present market value is nearly $\$ 6.5$ billion and projected to reach some $\$ 9$ billion seaweed global market by 2024 . Aquaculture is recognized as the most sustainable means of seaweed production and accounts for approximately 27.3 million tons (more than 90\%) of global seaweed production per annum. Asian countries produced $80 \%$ for world markets where China alone produces half of the total demand. The top six seaweed producing countries are China, Indonesia, Philippines, Korea, and Japan.

Keywords: Seaweeds; Cancer Prevention; Hyperglycemia Management; Microalgae; Neuroprotection; Alimentary Disorders

Abbreviations: MiBP: monoisobutyl phthalate; MEP: monoethyl phthalate; $\sum$ DEHP: The molar sum of MEHHP and MEOHP; MEHP: mono(2-ethylhexyl) phthalate; MEOHP: mono(2-ethyl-5-oxohexyl) phthalate; WEF: World Economic Forum; IHDs: Ischemic Heart Diseases; UN-FAO: Food and Agriculture Organization of the United
Nations; GEBT: Gastric Emptying Breath Test; LMICs: Low and Middle Income Countries; CLA: Conjugated Linoleic Acid; SOFA: State of Food and Agriculture; UCP-1: Uncoupling protein-1; HbA1c: Hemoglobin A1c; HbA1c: Hemoglobin A1c; ERK: extracellular signal-regulated kinases; IBD: Inflammatory bowel disease; ACE: Angiotensin Converting Enzyme; OA: Osteoarthritis; 


\section{Advances in Pharmacology and Clinical Trials}

CYP1: Cytochrome P450 1; MAPK: Mitogen-Activated Protein Kinases; COX 2: Cyclooxygenase-2; PI3K/Akt: Phosphatidylinositol 3-Kinase/Protein Kinase B; NF- $\kappa B$ : Nuclear Factor Kappa-Light-Chain-Enhancer Of Activated B cells

\section{Obesity, Hypertension and Hyperglycemia Management}

According to the WHO, 2.3 billion adults are overweight and the prevalence is higher in females of childbearing age than males [1]. In the US, the economic burden is estimated to be about $\$ 100$ billion annually [2]. Worldwide obesity causes 2.8 million deaths per year and 35.8 million disability-adjusted life-years, some $45 \%$ of diabetes, $25 \%$ of IHDs and up to $41 \%$ of certain cancers [3]. Four major bioactive compounds from seaweeds which have the potential as anti-obesity agents are fucoxanthin, alginates, fucoidans and phlorotannins [4] (Figure 1). Alginates are amongst the seaweed fibers that are well-known for their anti-obesity effects. They have been shown to inhibit pepsin, pancreatic lipase [5], reduced body weight, BMI, and the blood glucose level [6], ameliorate fat accumulation, TG and TC [7] in experimental animals. Koo et.al, 2019 reported Fucoxanthin powder developed from microalga Phaeodactylum tricornutum plus CLA or Xanthigen improved lipid metabolism, reduced body weight gain and adipose tissue [8]. Individually, fucoxanthin lowers glycated hemoglobin, especially in in healthy subjects with a certain UCP1 genotype [9]. Mendez et al. [10] reported anti-obesogenic potential of seaweed dulse (Palmaria palmata) (Figure 2) in High-fat Fed mice. Seca, et al. [11] suggested that small peptides from seaweed may possess bioactivity, for example, of relevance for BP regulation]. Yang, et al. [12] reported Fucoidan A2 from the brown seaweed Ascophyllum nodosum (Figure 3) lowers lipid by improving reverse cholesterol transport in mice. Sørensen, et al, [13] reported improved HbA1C and lipid profile with Saccharina latissima or sugar kelp (Figure 4) in mice. Fucoidan taken twice daily for a period of 90 days did not markedly affect insulin resistance in obese, nondiabetic cohort [14], but attenuates obesityinduced severe oxidative damage [15], show anticoagulant activity [16], suppress fat accumulation [17], may improve obesity-induced OA [18], antioxidant and lipolytic activities [19]. Catarino, et al. (20] and 2017 reported Fucus vesiculosus (Figure 5) phlorotannin-rich extracts have significant effect on $\alpha$-glucosidase, $\alpha$ amylase and pancreatic lipase. Phlorotannins, farnesylacetones and other constituents from seaweeds have also been described for their potential use in hypertension due to their reported vasodilator effects [21]. Sun, et al. [22] reported the hydrogen bond and $\mathrm{Zn}$ (II) interactions between the peptides of Marine Macroalga Ulva intestinalis and ACE. In similar studies, peptides from Sargassum siliquosum, Sargassum polycystum [23], Fucus spiralis L [24], Palmaria palmata [25], Pyropia yezoensis, Undaria pinnatifida, Enteromorpha clathrate, Ulva rigida C, Gracilariopsis lemaneiformis, Pyropia columbina, Ecklonia cava Kjellman, Ecklonia stolonifera Okamura, Pelvetia canaliculate, Sargassum thunbergii [26], Porphyra yezoensis [27], Lomentaria catenata, Lithophyllum okamurae, Ahnfeltiopsis flabelliformis [28] show potential ACE inhibitory activities. Besides the activation of Ag II, ACE plays a concomitant role in the regulation of hypertension via the inactivation of an endothelium-dependent vasodilatory peptide, bradykinin [28,29]. Kammoun, et al. [30] reported hypolipidemic and cardioprotective effects of Ulva lactuca, which effectively counteracts cardiotoxic effects of hypercholesterolemic regime. In several studies Ulva species showed hypotensive, hypoglycemic, hypolipaemic and antiatherogenic properties [31-40]. Moreover, studies also support seaweed induced effects of postprandial lipoproteinaemia [41-43] postprandial hyperglycemia [44-55], lipid metabolism and atherosclerosis [56-70], reduce body weight [71-80], HbA1c $[13,34,52,55,81-90]$, reduce $\mathrm{BP} /$ episodes of hypertension $[11,26,28,46,49,53,66,80,91-102]$ and prevent obesity induced oxidative damage $[4,8,13,34,103-$ 120]. Increased seaweed consumption may be linked to the lower incidence of metabolic syndrome in eastern Asia [28].

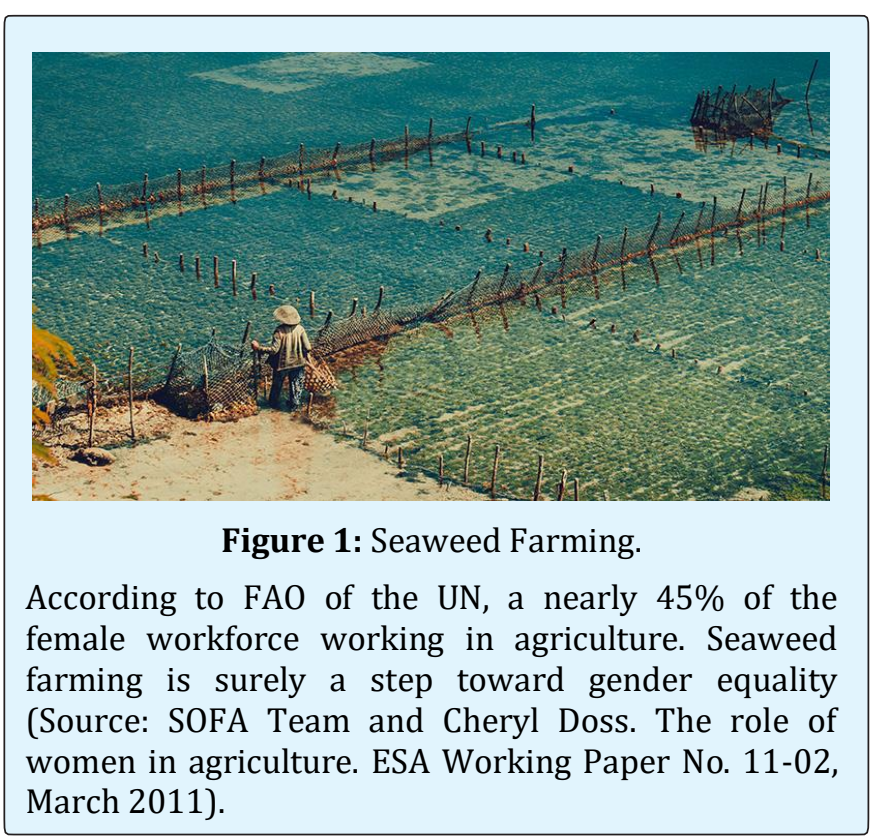




\section{Advances in Pharmacology and Clinical Trials}

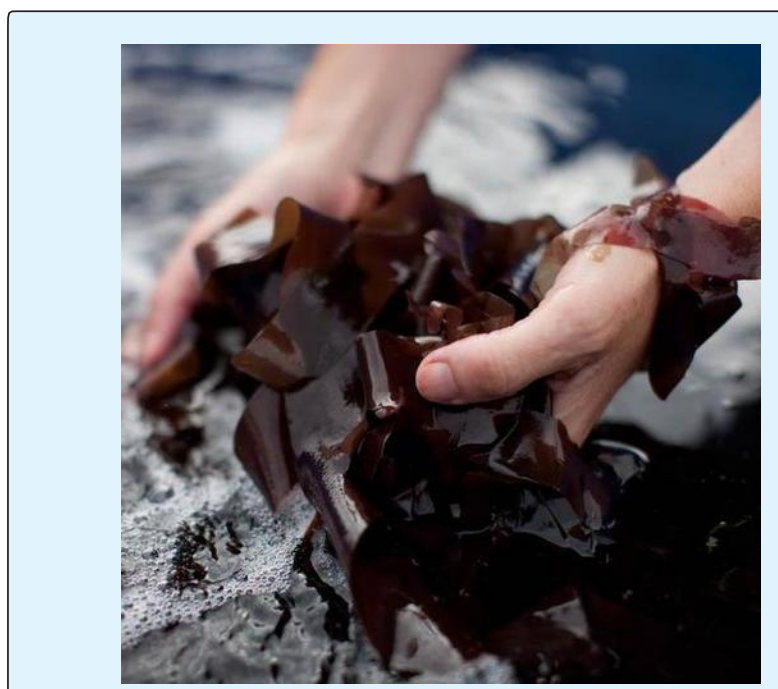

Figure 2: Palmaria palmate. (Source: What is Dulse Seaweed? Mara Seaweed October 17, 2017)

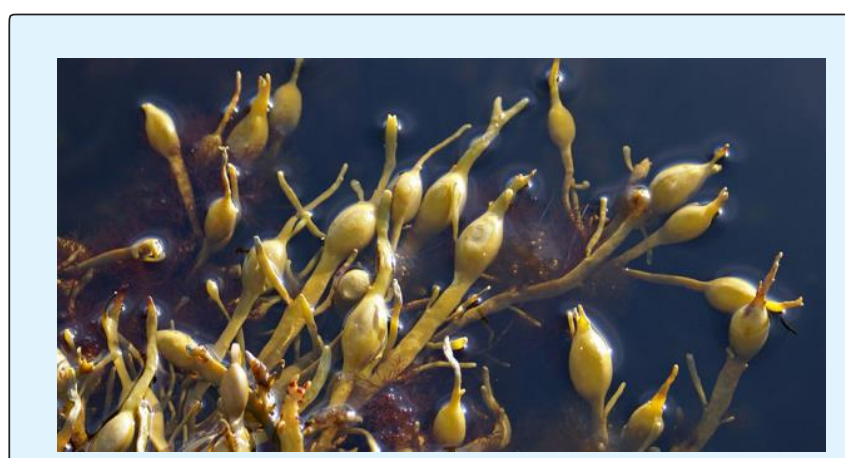

Figure 3: Ascophyllum nodosu. (Source: Ascophyllum nodosum. Jiloca Industrial, S.A. Agronutrientes Blog)

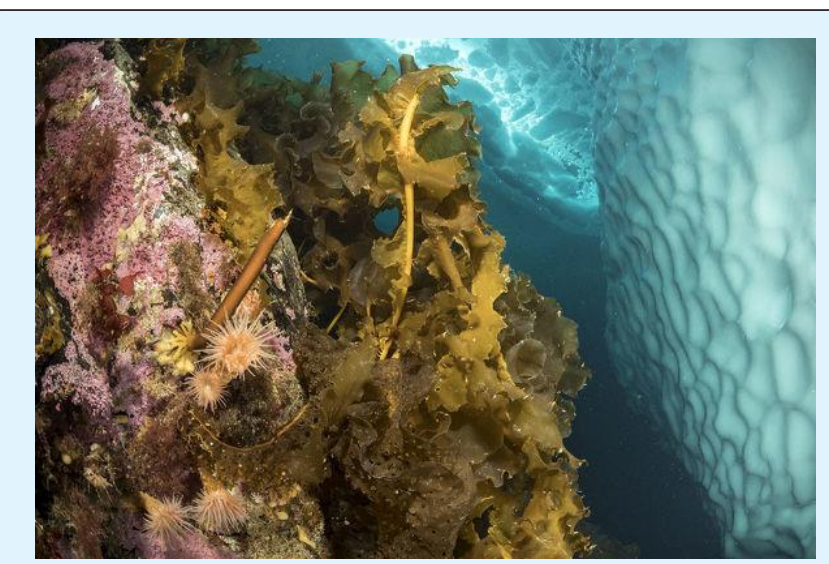

Figure 4: Saccharina latissima or sugar kelp. (Source: Nature Picture Library)

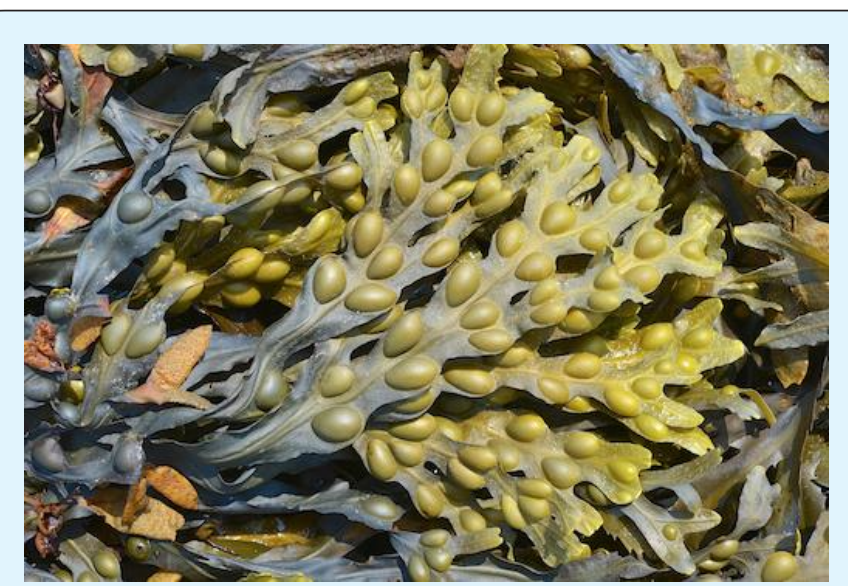

Figure 5: Fucus vesiculosus L. (Source: Seaweed Site of M.D. Guiry)

\section{Cancer Prevention \& Tumor Control}

In $2019,1,762,450$ new cancer cases and 606,880 cancer deaths are projected to occur in the United States [121]. Globally, cancer responsible for at least $20 \%$ of all mortality [122], 18.1 million new cancer, 9.5 million death in 2018 [123,124], 5- year prevalence 43.8 million [125], is predicted to rise by $61.4 \%$ to 27.5 million in 2040 [126]. Approximately $70 \%$ of deaths from cancer occur in LMICs [127]. Asia, Africa, and Latin America are collectively home to more than $50 \%$ of cancer patients; with more than half of global cancer-related mortalities occurring in Asia alone [128]. Cancer causes 46 billion in productivity lost in major emerging economies [129] and economic costs of tobacco-related cancers exceed USD 200 billion each year [130]. Compounds from natural sources with anti-proliferative activity represent an important and novel alternative to treat several types of cancer. Egregia menziesii (brown seaweed) (Figure 6) [131], Portieria hornemannii [132], Grateloupia elliptica [133] Sargassum serratifolium [134], Chitosan alginate (polysaccharide from seaweeds) [135-143], xanthophylls (astaxanthin, fucoxanthin) and Phlorotannins (phloroglucinol) obtained from the microalgae [144-155], are reported in brain tumor (glioblastoma) studies. astaxanthin and fucoxanthin are major marine carotenoids. Major seaweed sources of astaxanthin monoand di- esters are green algae (Haematococcus pluvialis (Figure 7), Chlorella zofingiensis, Chlorococcum) and redpigmented fermenting yeast Phaffia rhodozyma [156,157]. Fucoxanthin present in Chromophyta (Heterokontophyta or Ochrophyta), including brown seaweeds (Phaeophyceae) and diatoms (Bacillariophyta) [158]. 


\section{Advances in Pharmacology and Clinical Trials}

Several 2019 reviews reveal fucoidans (sulfated polysaccharide mainly derived from brown seaweed) in lung cancer management. Brown algae like Fucus vesiculosus, Turbinaria conoides, Laminaria japonica (Figure 8) are reported in inhibition of tumor migration and invasion, apoptosis induction and inhibition lung cancer cell progression respectively [159]. Fucus evanescens, Sargassum sp. (Figure 9), Saccharina Japonica was reported to inhibit proliferation and metastasis, and inducing apoptosis in vitro [160]. Undaria pinnatifida acted on ERK1/2 MAPK and p38, PI3K/Akt signaling, $F$. evanescens increased metastatic activity of cyclophosphamide and showed cytolytic activity of natural killer cells in 2 different studies and $F$. vesiculosus decreased NF- $\mathrm{BB}$ in LLC [161]. U. pinnatifida was found to show average antitumor and superior efficacy against LLC in review of Misra, et al. [162].

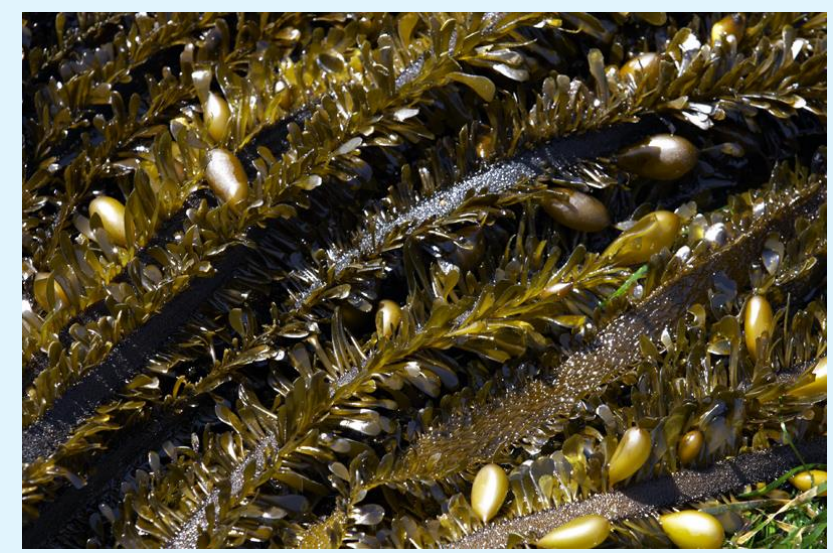

Figure 6: Egregia menziesii brown seaweed. (Source: University of British Columbia Garden)

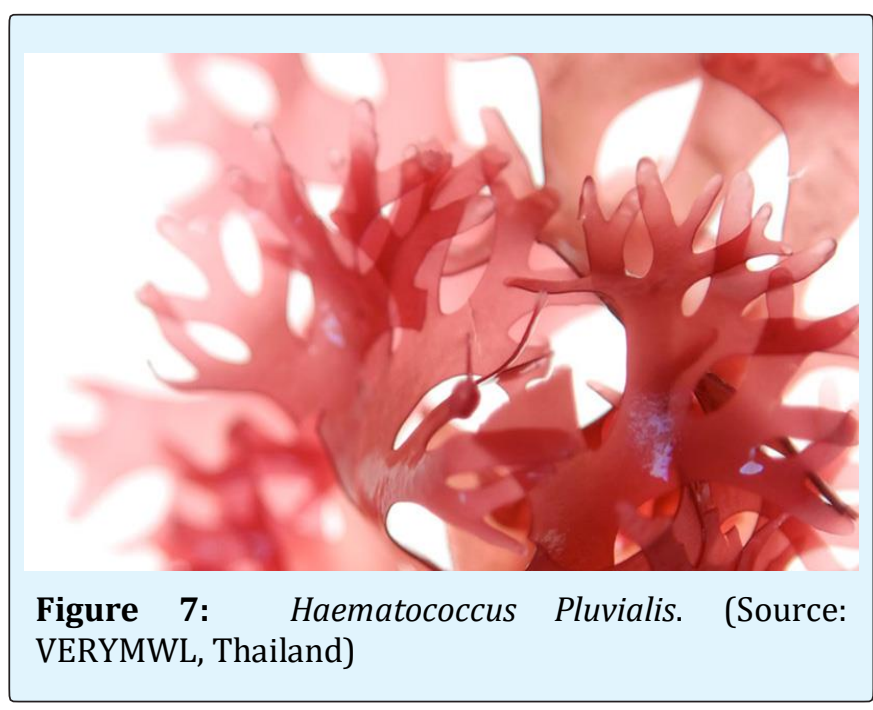

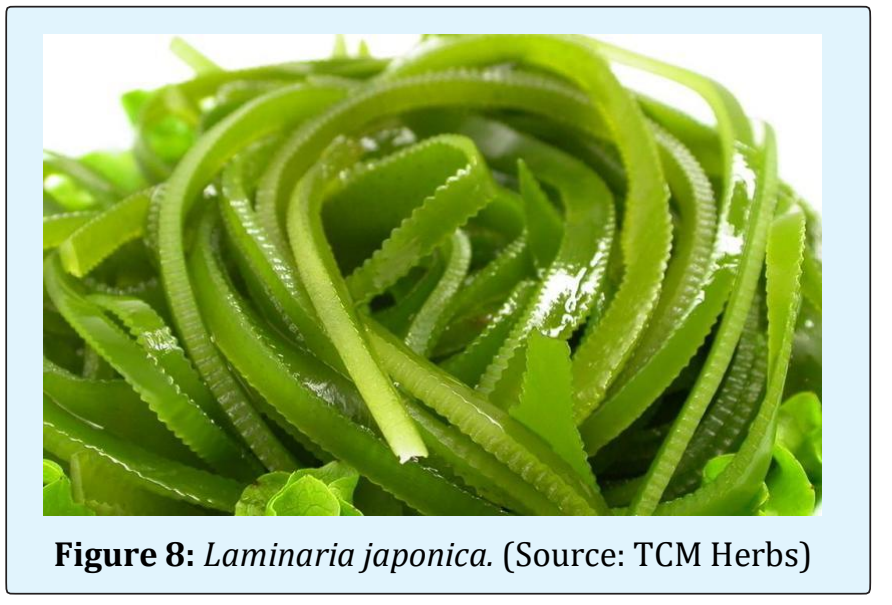
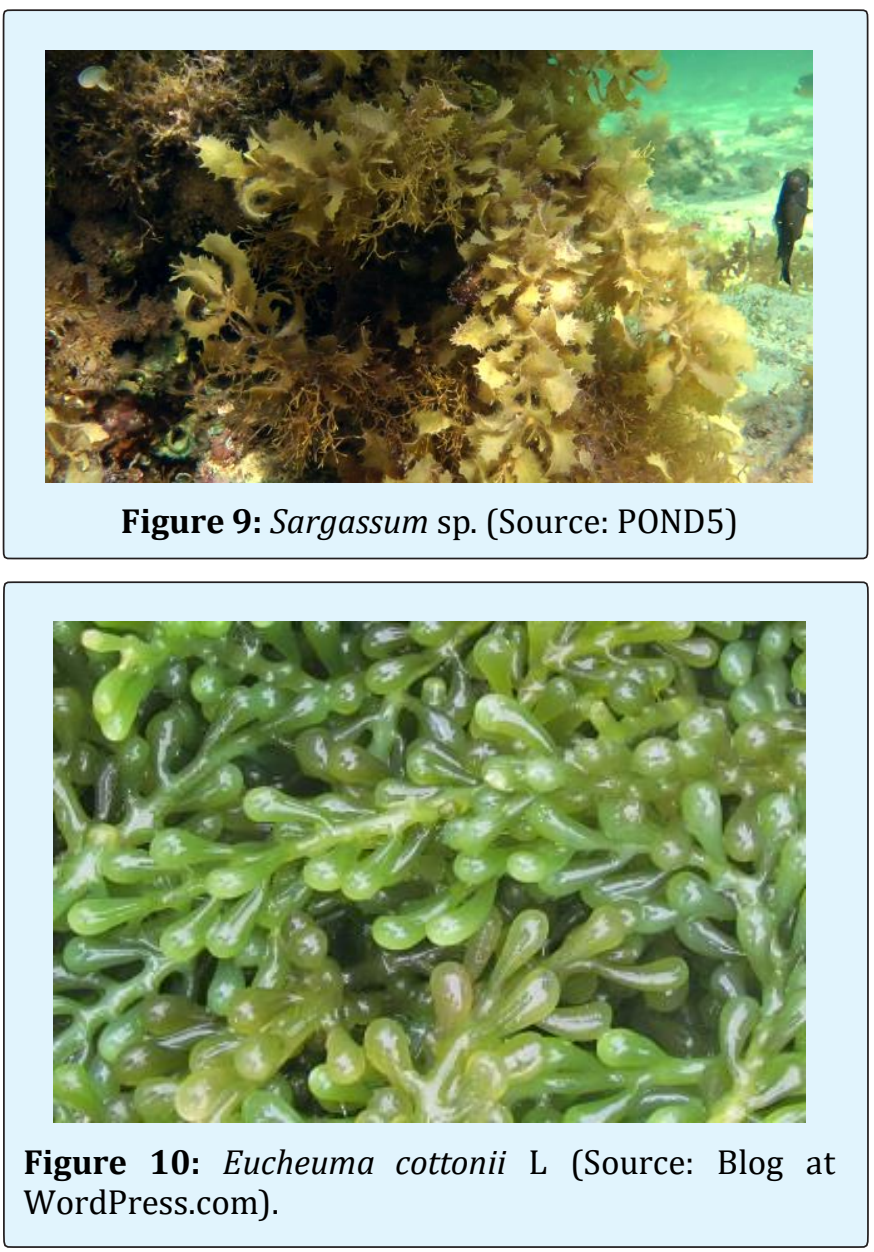

Sponge alkaloids from Aaptos showed potential in human lung adenocarcinoma A549, from Fascaplysinopsis exerted an anti-proliferative and pro-apoptotic effect in lung cancer, from blue sponge Xestospongia showed apoptosis as well as stimulate anoikis in H460 lung cancer cells in review by Ercolano, et al. [163]. The most common breast 


\section{Advances in Pharmacology and Clinical Trials}

cancer type is the invasive ductal carcinoma accounting for $70-80 \%$ of all breast cancers diagnosed [164]. Brown seaweed fucoidan inhibited human breast cancer progression by upregulating microRNA (miR)-29c and downregulating miR-17-5p, thereby suppressing their target genes [165]. Lophocladia sp (Lophocladines), Fucus sp (fucoidan), Sargassum muticum (polyphenol), Porphyra dentata (sterol fraction), Cymopolia barbata (CYP1 inhibitors), Gracilaria termistipitata was found to be effective in breast cancer studies [166]. High Urokinasetype plasminogen activator receptor (UPAR) expression predicts for more aggressive disease in several cancer types [167], dietary seaweed may help lowering breast cancer incidence by diminishing levels of UPAR [168]. The tropical edible red seaweed Eucheuma cottonii L. (Figure 10 ) is rich in polyphenols that exhibited strong anticancer effect with enzyme modulating properties [169]. Jazzara et al. [170] concluded that $\lambda$-carrageenan (sulfated galactans found in certain red seaweeds) could be a promising bioactive polymer, showed a remarkable inhibitory effect on MDA-MB-231(triple negative breast cancer cell line) cell migration [171]. Several studies support polyphenols [172-176], flavonoids [177-186], fucoidan [159,160,166,187-195], lutein/zeaxanthin [196200], other seaweed alkaloids, peptides, tannins and polysaccharides $[132,164,201-210]$ in breast cancer management. The number of deaths from colorectal cancer in Japan continues to increase [211], it is the third most common diagnosis and second deadliest malignancy for both sexes combined [212]. It has been projected that there will be 140,250 new cases of colorectal cancer in 2018, with an estimated 50,630 people dying of this disease [213]. High intake of red and processed meat and alcohol increase the risk of colorectal cancer [214]. $U$. pinnatifida [159,188,215-221], Saccharina latissimi [222], Fucus vesiculosus $[117,160,223,224]$, Sargassum hemiphyllum $[155,225,226]$ have proven efficacy in this situation. Also, Algae derived astaxanthin [150,227-232] fucoxanthin [233-237] lutein and zeaxanthin [238-241] polyphenols [242-246] shown individual excellence.

\section{Neuroprotection in Stroke, Alzheimer's and Parkinsonism}

Stroke is a leading cause for disability and morbidity associated with increased economic burden due to treatment and post-stroke care. Acute ischemic stroke has enormous societal and financial costs due to rehabilitation, long-term care, and lost productivity. Between 2010 and 2030, stroke is expected to increase by more or less $60 \%$ in men and $40 \%$ in women [248]. Several studies reported neuroprotective role of astaxanthin and fucoxanthin [145,248-268] in stroke prevention, Alzheimer's, Parkinsonism and other neurodegenerative diseases. Barbalace, et al. [269] reported that marine algae inhibit pro-inflammatory enzymes such as COX-2 and iNOS, modulate MAPK pathways, and activate NK-kB. Neorhodomela aculeate, Rhodomela confervoides [26,270], Ecklonia cava (Figure 11) [271-275], Laminaria japonica [276-281], Fucus vesiculosus [282-287], Sargassum spp. [288-295], Saccorhiza polyschide [283], Codium tomentosum [296], Ulva spp [256,267,293,297-300], Ecklonia maxima [256,301-303], Gracilaria spp. (Figure 12) [296,304-311], Gelidium pristoides [312,313], Halimeda incrassate [314,315], Bryothamniom triquetrum [316-318], Chondrus crispus (Figure 13) [319,320], Hypnea valentiae (Figure 14) [298], Ecklonia stolonifera [321-323] were reported in several studies as neuro-protectives and suggested in neurodegenerative situations or already in use in as such conditions.

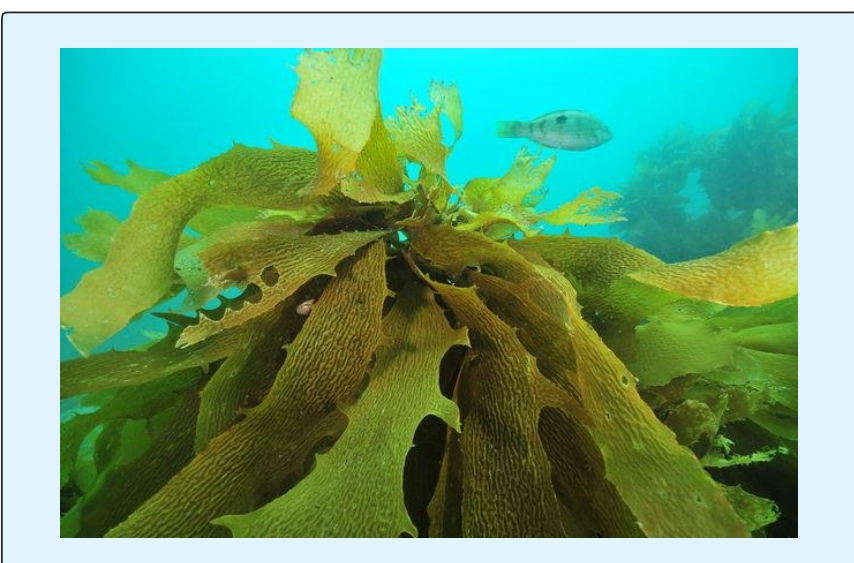

Figure 11: Ecklonia cava. (Source: Predator Nutrition)

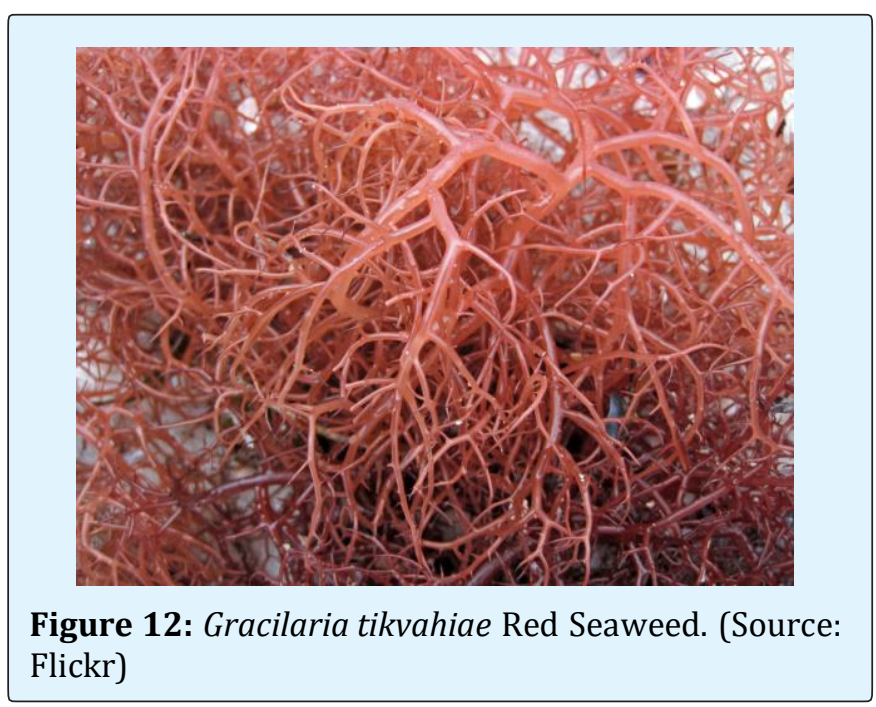




\section{Advances in Pharmacology and Clinical Trials}

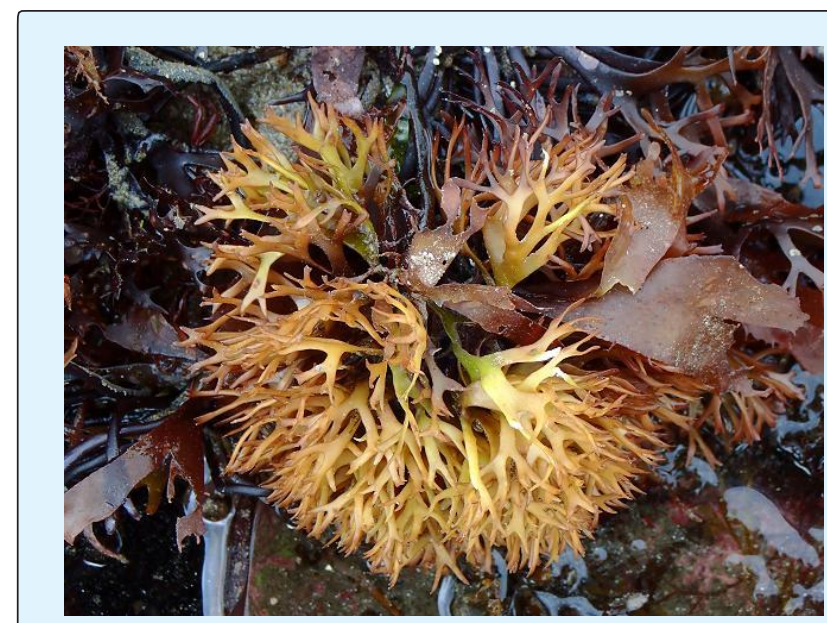

Figure 13: Chondrus crispus - Carragheen or Irish Moss. (Source: APHOTOMARINE)

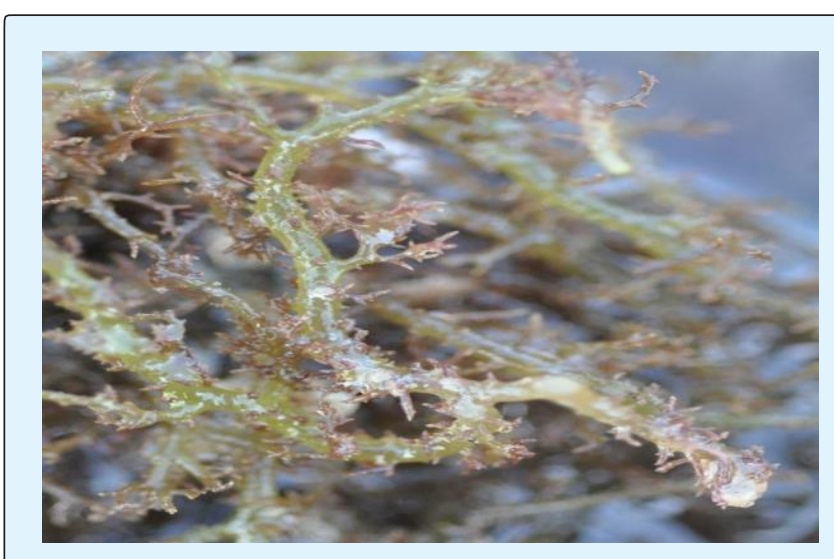

Figure 14: Hypnea valentiae. (Source: iNaturalist).

\section{Alimentary Disorders}

In the USA, the sales of prescription GI therapeutic drugs were $\$ 25$ billion, the 10 th leading therapeutic class in terms of sales [324], spend $\$ 135.9$ billion for GI diseases in 2015 [325]. Urbanization, western diet, hygiene, and childhood immunological factors are associated with IBD in Asia [326]. On the other hand, 14\% of the global population is affected by IBS and $30 \%$ by constipation $[327,328]$. Na- alginate, has been used in the treatment of heartburn and GERD, although ESPGHAN/NASPGHAN Guidelines do not recommend it's use in chronic GERD [329,330]. The $\left[{ }^{13} \mathrm{C}\right]$-Spirulina platensis GEBT is an easy to measure of gastric emptying with accuracy [331-333]. Laminaria japonica (vomiting, hemorrhoids, IBD, probiotic synergist) [334,335], Eucheuma cottonii (IBD, hepatoprotective, anti-food allergy) [336-338], Caulerpa Mexicana (Figure 15)
(Gastroprotective, IBD) [339-341], Hypnea musciformis (IBD) [336,342], Fucus vesicolosus (gastroprotective, ulcerative colitis) [117,343], Laminaria hyperborean, Laminaria digitate (IBD) [344,345], Undaria pinnatifida (Figure 16) (improves gut health) are reported in gut health modulation [346]. In addition, seaweed polysaccharides are atypical in structure to terrestrial glycans, and were found to resist gastric acidity, host digestive enzymes, and GI absorption [347]. Maternal seaweed extract supplementation can reduce both sow fecal Enterobacteriaceae populations at parturition and piglet E. coli populations at weaning [348]. Also, seaweeds are good source of prebiotics that improve intestinal microbiota and may exert positive effects on IBD and IBS [349,350].

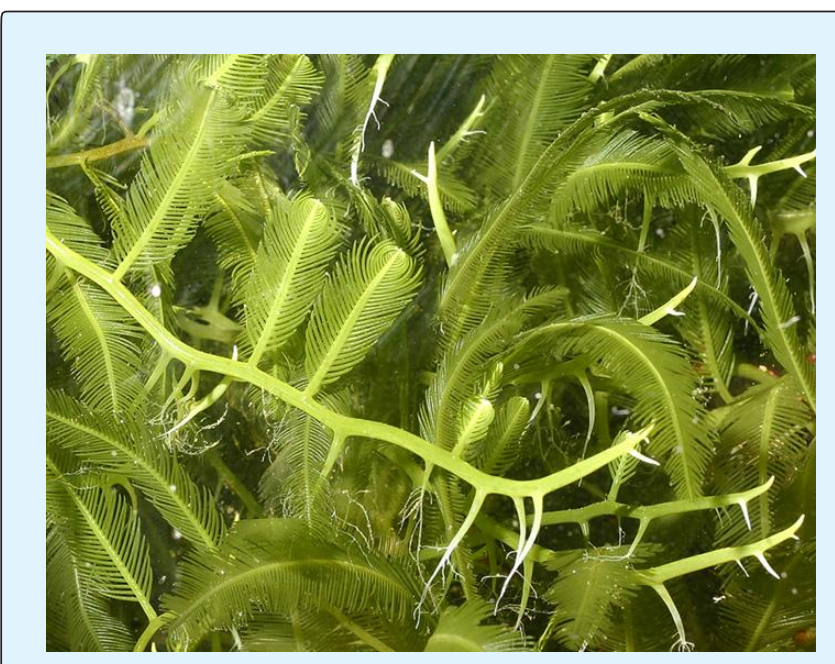

Figure 15: Caulerpa Mexican. (Source: Reefs.com)

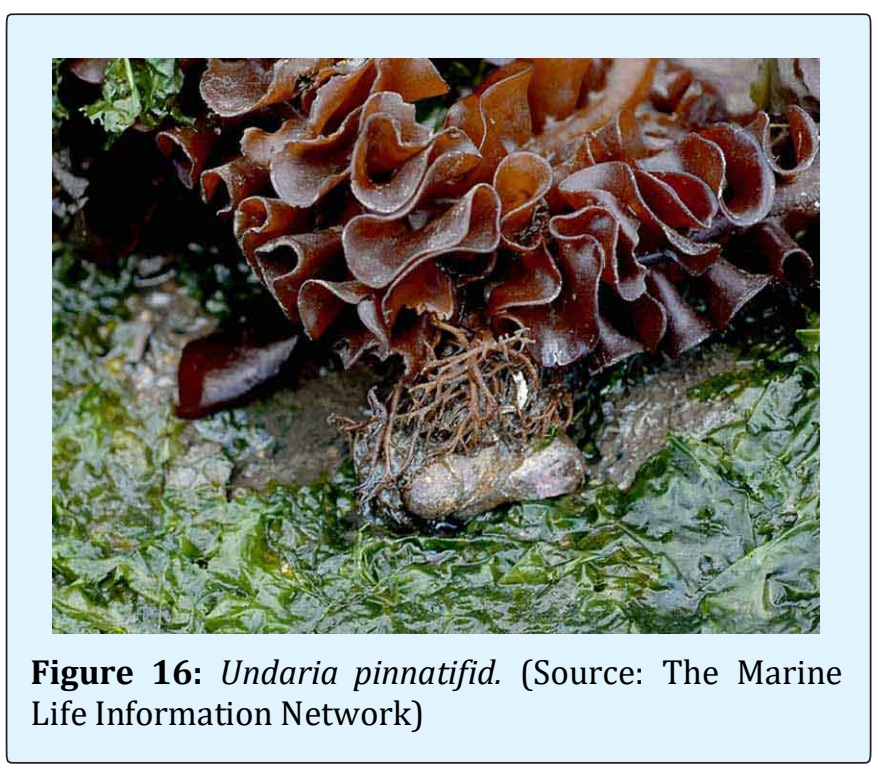




\section{Advances in Pharmacology and Clinical Trials}

\section{Thyroid Function}

Seaweeds are rich source of Iodine and Tyrosine [351], palatable and acceptable to consumers as a whole food or as a food ingredient and effective as a source of iodine in an iodine-insufficient population [352]. In addition, daily diet should include thyroid boosting foods like those rich in iodine, amino acid tyrosine, minerals like selenium, zinc, copper, iron, various vitamins including, B2, B3, B6, C and E [353]. Edible seaweeds are rich in these vitamins and minerals [95]. Although high iodine intakes are well tolerated by most healthy individuals, but in some people, it may precipitate hyperthyroidism, hypothyroidism, goiter, and/or thyroid autoimmunity [354]. Excess intake of iodine through seafood consumption is a suspected risk factor for thyroid cancer [355]. Also, some seaweeds are contaminated with arsenic, mercury, cadmium and other heavy metals that have positive association with thyroid hormones in adults [356-360].

\section{Analgesic and Anti-Inflammatory Potential}

Neuropathic pain estimates of $60 \%$ among those with chronic pain. Mild -to-moderate pain may be relieved by non-drug techniques alone [128]. 1g of brown seaweed extract ( $85 \% F$. vesiculosus fucoidan) daily could reduce joint pain and stiffness by more than $50 \%[361,362]$. Association between algae consumption and a lower incidence of chronic degenerative diseases is also reported for The Japanese [363]. Carrageenan has been widely used as a tool in the screening of novel antiinflammatory drugs [364]. Among others, Porphyra vietnamensis [365,366], Eucheuma Cottonii [367], Dichotomaria obtusata (Figure 17) [368], Cystoseira sedoides, Cladostephus spongiosis, Padina pavonica (Figure 18) [369], Ecklonia cava (due to phlorotannins) [370372], Caulerpa racemose [373], Sarcodia ceylanica [374], actinotrichia fragilis [375], Dictyota menstrualis (Figure 19) [376], Gracilaria cornea [377], Gracilaria birdiae [378], Class Phaeophyceae, Rhodophyceae and Chlorophyceae [379], Caulerpa curpressoides [380,381], Ulva lactuca (Figure 20) [382], Sargassum wightii and Halophila ovalis [383], Grateloupia lanceolate [384], Sargassum fulvellum and Sargassum thunbergii [385], Briareum excavatum [386], Caulerpa racemose [387], Sargassum hemiphyllum [388], Laurencia obtusa [389], Caulerpa kempfii [390] Caulerpa cupressoides [391] are reported for their analgesic and anti-inflammatory properties.

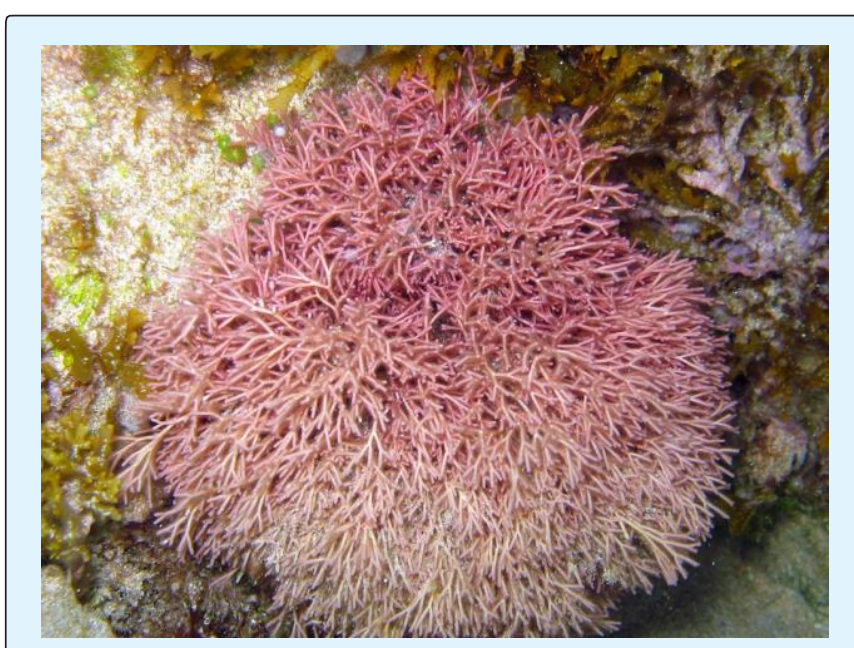

Figure 17: Dichotomaria obtusata, Tubular Thicket Algae (reefguide.org).
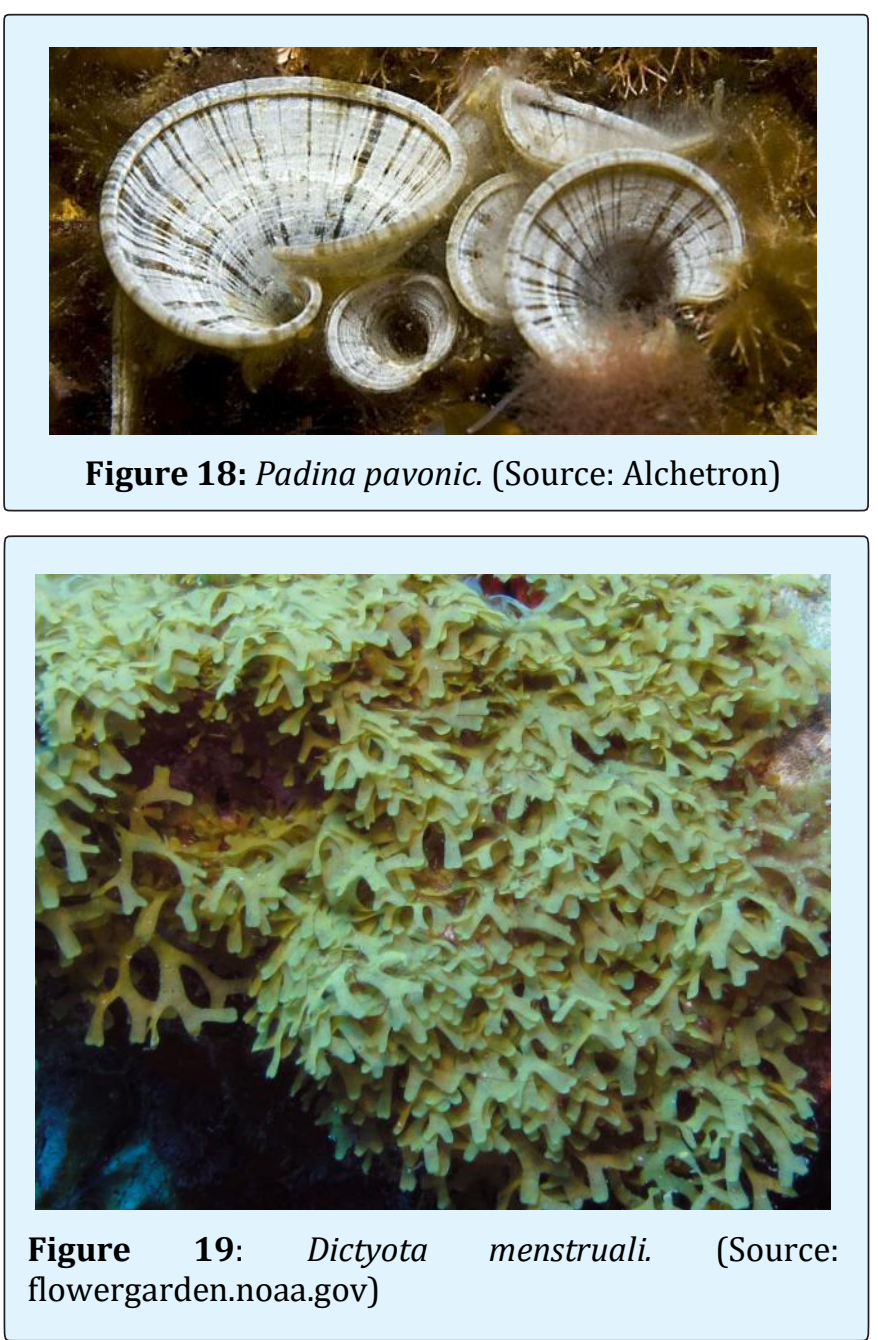


\section{Advances in Pharmacology and Clinical Trials}

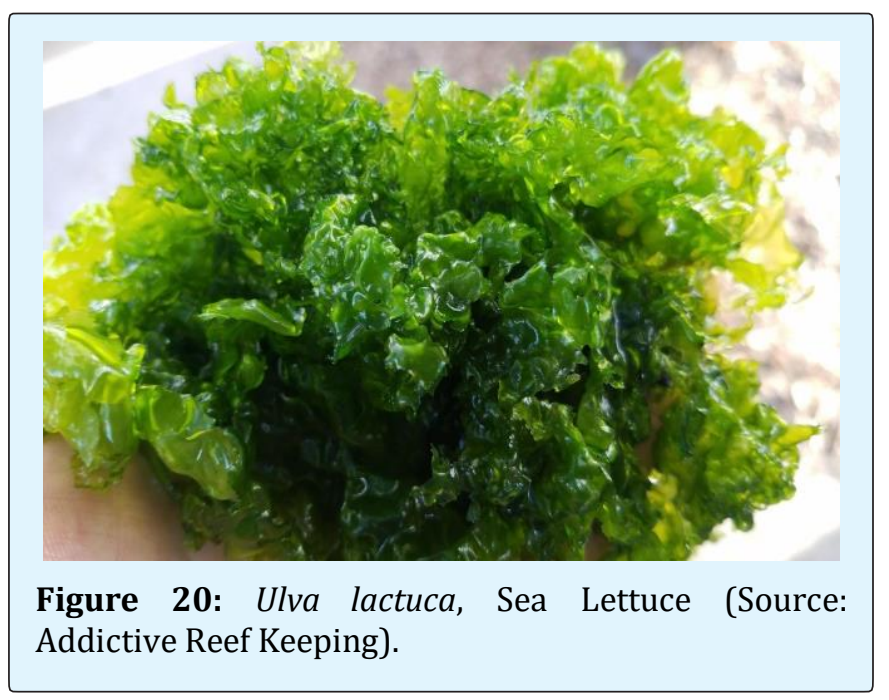

\section{Antimicrobial Properties}

Rising antimicrobial resistance is a threat to modern medicine. Infections with resistant organisms have higher morbidity and mortality, are costlier to treat and estimated to cause 10 million deaths annually by 2050 with global economic loss US $\$ 100$ trillion [392-394]. Lu et al. [394] reported Laminaria japonica, Sargassum, Gracilaria sp. and Porphyra dentata potentiated the activities of macrolides against E. coli. Carragelose ${ }^{\circledR}$ (first marketed product from algae) in the has ability to block viral attachment to the host cells being effective against a broad spectrum of respiratory viruses [395]. Besednova, et al, [396] reported that fucoidans, carrageenans, ulvans, lectins, and polyphenols are biologically active compounds from seaweeds that target proteins or genes of the influenza virus and host components (Table 1).

\begin{tabular}{|c|c|}
\hline Red Seaweed & Organisms \\
\hline Alsidium corallinum & Escherichia coli, Klebsiella pneumoniae, Staphylococcus aureus \\
\hline Ceramium rubrum & E. coli, Enterococcus faecalis, S. aureus \\
\hline Ceramium virgatum & $\begin{array}{l}\text { Salmonella enteritidis, E. coli, Listeria monocytogenes, Bacillus } \\
\text { cereus }\end{array}$ \\
\hline Chondrocanthus acicularis & E. coli, K. pneumoniae, E. faecalis, S. aureus \\
\hline Chondracanthus canaliculatus & S. aureus, Streptococcus pyogenes \\
\hline Chondrus crispus & L. monocytogenes, Salmonella abony, E. faecalis, P. aeruginosa \\
\hline C. crispus & $\begin{array}{l}\text { Pseudoalteromonas elyakovii, Vibrio aestuarianus, Polaribacter } \\
\text { irgensii, Halomonas marina, Shewanella putrefaciens }\end{array}$ \\
\hline Corallina elongata & $\begin{array}{l}\text { B. subtilis, S. aureus, E. coli, Salmonella typhi, K. pneumoniae, } \\
\text { Candida albicans }\end{array}$ \\
\hline Gelidium attenatum & E. coli, K. pneumoniae, E. faecalis, S. aureus \\
\hline Gelidium micropterum & V. parahaemolyticus, V. alcaligenes \\
\hline Gelidium pulchellum & E. coli, E. faecalis, S. aureus \\
\hline Gelidium robustum & S. aureus, S. pyogenes \\
\hline Gelidium spinulosum & E. coli, E. faecalis, S. aureus \\
\hline Gracilaria dura & V. ordalii, V. alginolyticus \\
\hline Gracilaria gracilis & V. salmonicida \\
\hline Grateloupia livida & S. aureus, E. coli, P. aeruginosa \\
\hline Gracilaria ornata & E. coli \\
\hline Gracilaria subsecundata & S. aureus, S. pyogenes \\
\hline \multicolumn{2}{|l|}{ Green Seaweed } \\
\hline Boodlea composita & $\begin{array}{l}\text { V. harveyi, V. alginolyticus, V. vulnificus, V. parahaemolyticus, } V \text {. } \\
\text { alcaligenes }\end{array}$ \\
\hline Bryopsis pennata & V. vulnificus, V. parahaemolyticus \\
\hline Caulerpa lentillifera & E. coli, Staphylococcus aureus, Streptococcus sp., Salmonella sp. \\
\hline Caulerpa parvula & V. vulnificus, V. alcaligenes \\
\hline Caulerpa racemosa & E. coli, S. aureus, Streptococcus sp., Salmonella sp. \\
\hline
\end{tabular}




\section{Advances in Pharmacology and Clinical Trials}

\begin{tabular}{|c|c|}
\hline Chaetomorpha aerea & Bacilus subtilis, Micrococcus luteus, S. aureus \\
\hline Chaetomorpha linum & V. ordalii, V. vulnificus \\
\hline Cladophora albida & $\begin{array}{l}\text { V. harveyi, V. alginolyticus, } V . \text { vulnificus, V. parahaemolyticus, } V \text {. } \\
\text { alcaligenes }\end{array}$ \\
\hline Cladophora glomerata & V. fischeri, V. vulnificus, V. anguillarum, V. parahaemolyticus \\
\hline \multicolumn{2}{|l|}{ Brown Seaweed } \\
\hline Chnoospora implexa & S. aureus, S. pyogenes \\
\hline Cladophora rupestris & $\begin{array}{l}\text { E. coli, S. aureus, P. aeruginosa, V. harveyii, V. parahaemolyticus, } \\
\text { V. alginolyticus }\end{array}$ \\
\hline C. rupestris & $\begin{array}{l}\text { E. coli, } S \text {. aureus, P. aeruginosa, V. harveyii, V. parahaemolyticus, } \\
\text { V. alginolyticus }\end{array}$ \\
\hline C. rupestris & E. coli, S. aureus, P. aeruginosa, V. harveyii, V. parahaemolyticus \\
\hline Colpomenia sinuosa & $\begin{array}{l}\text { S. aureus, } \text { S. pyogenes, B. subtilis, S. aureus, E. coli, S. typhi, K. } \\
\text { pneumoniae, C. albicans }\end{array}$ \\
\hline Colpomenia tuberculata & S. aureus, Sreptococcus pyogenes \\
\hline Cystoseira osmundacea & S. pyogenes \\
\hline Cystoseira trinodis & S. aureus, B. subtilis, E. coli, P. aeruginosa \\
\hline Dictyopteris delicatula & S. aureus, S. pyogenes \\
\hline Dictyopteris undulata & S. aureus, S. pyogenes \\
\hline Dictyota dichotoma & S. aureus, B. subtilis, E. coli, P. aeruginosa \\
\hline Dictyota flabellata & S. aureus, S. pyogenes \\
\hline Dictyota indica & S. aureus, B. subtilis, E. coli, P. aeruginosa \\
\hline Dictyota sp. & S. aureus, Enterococcus faecalis, $P$. aeruginosa \\
\hline Eisenia bicyclis & S. aureus, S. epidermidis, Propionibacterium acnes \\
\hline
\end{tabular}

Table 1: Antimicrobial activity of different solvent extracts from seaweeds [397].

\section{Other Health Issues}

Walsh, et al. (398) reported osteogenic potential of brown seaweeds Laminaria digitata and Ascophyllum nodosum. Seaweed contains several compounds with antioxidant properties (phlorotannins, pigments, tocopherols, flavonoids, polyphenols and polysaccharides) [399]. Antioxidant properties of Fucus vesiculosus and Ascophyllum nodosum (due to phlorotannins) [399], Turbinaria conoides (2H-pyranoids) [400], Ulva clathrate (phenolics and flavonoid contents) [401], Bifurcaria bifurcate (Figure 21) (diterpenes eleganolone and eleganonal) [402], Cystoseira spp. (phenolic constituents) [119], Sargassum siliquastrum (phenolic compounds, ascorbic acid) [403], Ulva compressa (phenolic contents) [404], Saccharina japonica (polysaccharides) and Sargassum horneri (phenolic contents) [405,406], Halophila ovalis (Figure 22) and Halophila beccarii (flavonoids) [407,408], Cystoseira sedoides (mannuronic acid than guluronic acid) [369,409,410], Caulerpa peltata, Gelidiella acerosa, Padina gymnospora, and Sargassum wightii (phenols and flavonoids) [411], Ecklonia cava Kjellman (polyphenols) [412,413], Undaria pinnatifida (phlorotannins) [414] are well reported. Most other medicinal effects are mainly due to presence of these antioxidants. Mesripour, et al. (415) reported antidepressant effects of Sargassum plagyophylum. Ecklonia bicyclis, Tribulus terrestris improved sexual and ejaculation function and sexual QoL [416]. Chronic pain is often associated with sexual dysfunction, suggesting that pain can reduce libido [416]. However, red algae (especially sea moss/ Gracilaria spp.), Hypnea musciformis (Vermifuge), Porphyra crispata are known to have aphrodisiac properties [417-419]. Thrombotic diseases are reported to contribute to $30 \%$ early deaths globally [420]. Ulva rigida [421], Udotea flabellum (Figure 23) [422], ulvans, and their oligosaccharides [380], Nemacystus decipieus, Undaria pinnatifida [423], Porphyra yezoensis, Coscinoderma mathewsi, Sargassum micranthum, Sargassum yezoense, Canistrocarpus cervicornis (Figure 24), Dictyota menstrualis, Ecklonia Kurome, Ecklonia spp. [424] have shown anticoagulant and anti-thrombotic properties. He, et al. (425] reported that seaweed consumption may be a 


\section{Advances in Pharmacology and Clinical Trials}

dietary predictor of elevated MEP, MiBP, and $\sum$ DEHP concentrations among pregnant women. Urolithiasis affects approximately $10 \%$ of the world population and is strongly associated with calcium oxalate $(\mathrm{CaOx})$ crystals. Gomes, et al. [426] reported anti-urolithic effect of green seaweed Caulerpa cupressoides [426]. Grateloupia elliptica has the potential to treat alopecia via inhibitory activity against Pityrosporum ovale [427]. Strong fungusinhibitory effects of Ochtodes secundiramea and Laurencia dendroidea extracts were observed Banana and papaya during storage [428]. Marine macroalgae are a promising source of diverse bioactive compounds with applications in the biocontrol of harmful cyanobacteria blooms [429].
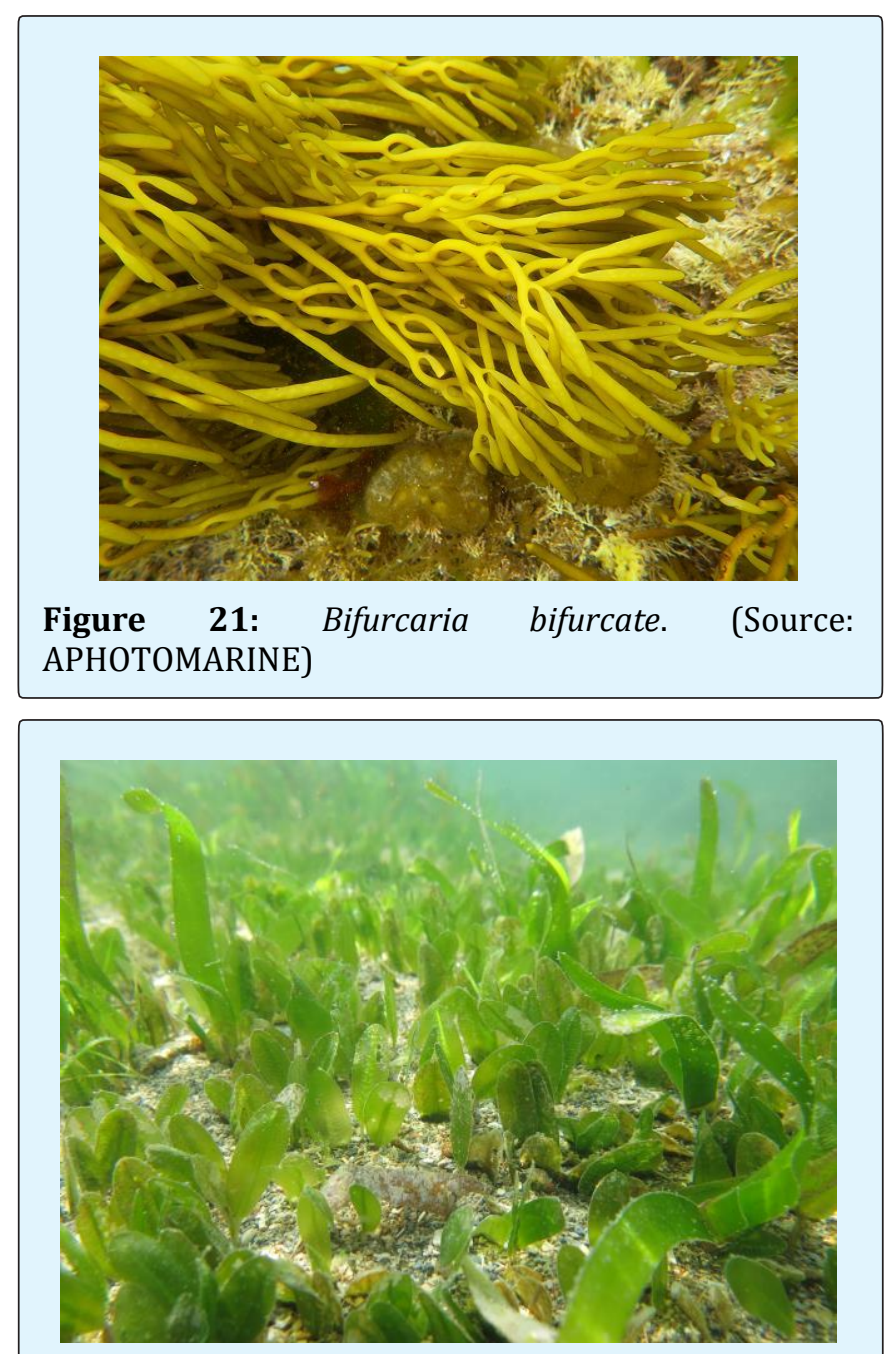

Figure 22: Halophila ovalis, Spoon Seagrass. (Source: CoMBINe)
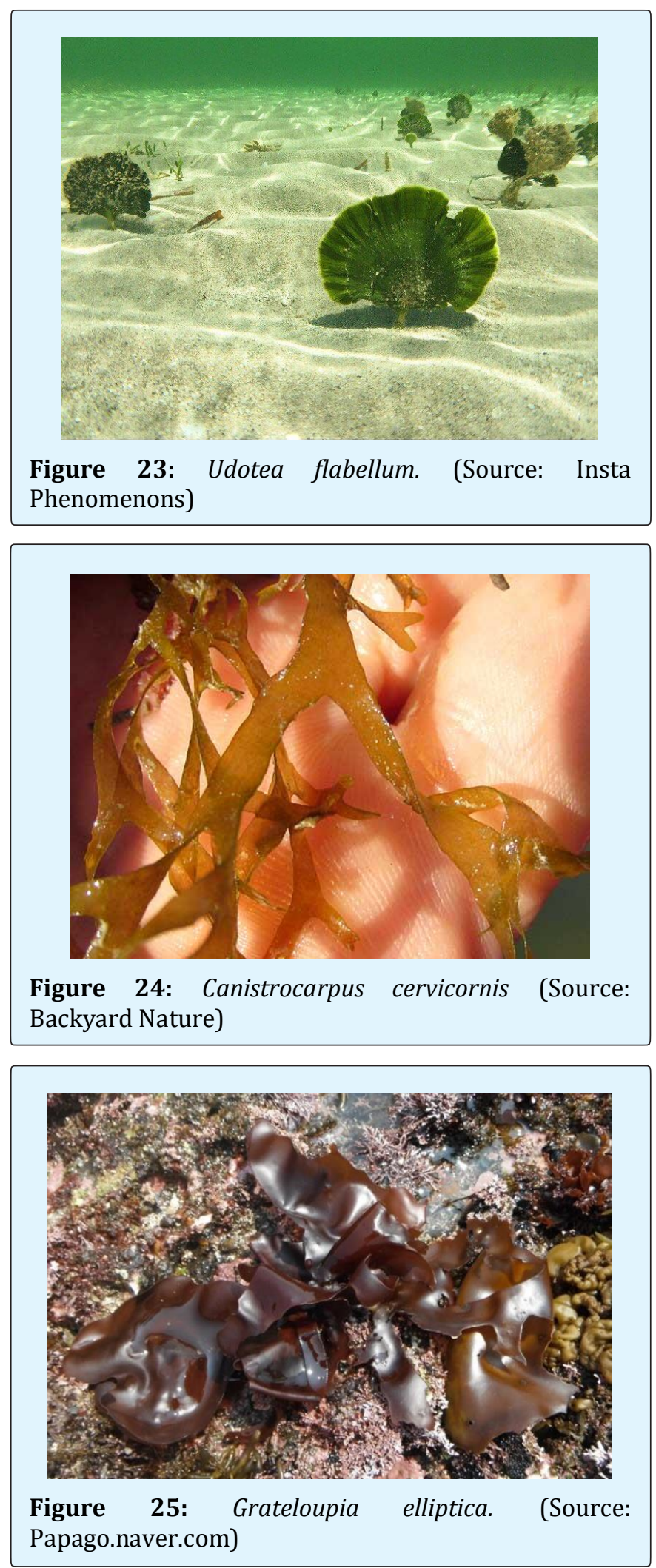


\section{Advances in Pharmacology and Clinical Trials}

\section{Conclusion}

Seaweeds are well-known for their exceptional capacity to accumulate essential minerals and trace elements needed for human nutrition, although their levels are commonly very variable depending on their morphological features, environmental conditions, and geographic location. Food security, legislative measures to ensure monitoring and labeling of food products are needed. Being subject to environmental influences from its habitat, seaweeds also entail water-borne health risks such as organic pollutants, toxins, parasites, and heavy metals. Having in mind the serious environmental problems raised in coastal areas by urbanization and industrialization, the concentration of toxic elements in edible macroalgae is now a growing concern, mainly considering their increment in Western diet. Although many studies demonstrated their therapeutic value in various ailments but most of them performed on experimental animals. Proper labelling is necessary along with instruction of content, source and use. Furthermore, controlled human intervention studies with healthrelated end points to elucidate therapeutic efficacy are required.

\section{Acknowledgement}

I'm thankful to Dr. Paul Cherry, Nutrition Innovation Centre for Food and Health, Ulster University, UK for his valuable time to audit my paper and for his thoughtful suggestions. I'm also grateful to seminar library of Faculty of Pharmacy, University of Dhaka and BANSDOC Library, Bangladesh for providing me books, journal and newsletters.

\section{Financial Disclosure or Funding: N/A}

Conflict of Interest: The author declares that he has no competing interests.

\section{Informed Consent: N/A}

\section{Author contributions: N/A}

\section{References}

1. Ma RCW, Schmidt MI, Tam WH, McIntyre HD, Catalano PM (2016) Clinical management of pregnancy in the obese mother: before conception, during pregnancy, and post partum. Lancet Diabetes Endocrinol 4(12): 1037-1049.
2. Panuganti KK, Gossman WG (2019) Obesity. In: Stat Pearls.

3. Dagne S, Gelaw YA, Abebe Z, Wassie MM (2019) Factors associated with overweight and obesity among adults in northeast Ethiopia: a cross-sectional study. Diabetes Metab Syndr Obes 12: 391-399.

4. Wan Loy C, Siew Moi P (2016) Marine Algae as a Potential Source for Anti-Obesity Agents. Mar Drugs 14(12): 222.

5. Chater PI, Wilcox M, Cherry P, Herford A, Mustar S, et al. (2016) Inhibitory activity of extracts of Hebridean brown seaweeds on lipase activity. J Appl Phycol 28: 1303-1313.

6. Tran VC, Cho SY, Kwon J, Kim D (2019) Alginate oligosaccharide (AOS) improves immuno-metabolic systems by inhibiting STOML2 overexpression in high-fat-diet-induced obese zebrafish. Food Funct 10(8): 4636-4648.

7. Wang X, Liu F, Gao Y, Xue CH, Li RW, et al. (2018) Transcriptome analysis revealed anti-obesity effects of the Sodium Alginate in high-fat diet -induced obese mice. Int J Biol Macromol 115: 861-870.

8. Koo SY, Hwang JH, Yang SH, Um JI, Hong KW, et al. (2019) Anti-Obesity Effect of Standardized Extract of Microalga Phaeodactylum tricornutum Containing Fucoxanthin. Mar Drugs 17(5).

9. Mikami N, Hosokawa M, Miyashita K, Sohma H, Ito YM, et al. (2017) Reduction of HbA1c levels by fucoxanthin-enriched akamoku oil possibly involves the thrifty allele of uncoupling protein 1 (UCP1): a randomised controlled trial in normal-weight and obese Japanese adults. J Nutr Sci 6: e5.

10. Mendez R, Miranda C, Armour C, Sharpton T, Stevens JF, et al. (2019) Antiobesogenic Potential of Seaweed Dulse (Palmaria palmata) in High-fat Fed C57BL/6 J Mice (P21-014-19). Current Developments in Nutrition 3(S1): nzz041.P21-014-19.

11. Seca AML, Pinto DCGA (2018) Overview on the Antihypertensive and Anti-Obesity Effects of Secondary Metabolites from Seaweeds. Mar Drugs 16(7).

12. Yang Z, Liu G, Wang Y, Yin J, Wang J, et al. (2019) Fucoidan A2 from the Brown Seaweed Ascophyllum nodosum Lowers Lipid by Improving Reverse 


\section{Advances in Pharmacology and Clinical Trials}

Cholesterol Transport in C57BL/6J Mice Fed a HighFat Diet. J Agric Food Chem 67(20): 5782-5791.

13. Sorensen LE, Jeppesen $\mathrm{PB}$, Christiansen $\mathrm{CB}$, Hermansen K, Gregersen S (2019) Nordic Seaweed and Diabetes Prevention: Exploratory Studies in KKAy Mice. Nutrients 11(6).

14. Wright CM, Bezabhe W, Fitton JH, Stringer DN, Bereznicki LRE, et al. (2019) Effect of a Fucoidan Extract on Insulin Resistance and Cardiometabolic Markers in Obese, Nondiabetic Subjects: A Randomized, Controlled Trial. J Altern Complement Med 25(3): 346-352.

15. Ahn JH, Shin MC, Kim DW, Kim H, Song M, et al. (2019) Antioxidant Properties of Fucoidan Alleviate Acceleration and Exacerbation of Hippocampal Neuronal Death Following Transient Global Cerebral Ischemia in High-Fat Diet-Induced Obese Gerbils. Int J Mol Sci 20(3).

16. Wang $Y$, Xing $M$, Cao Q Ji A, Liang H, et al. (2019) Biological Activities of Fucoidan and the Factors Mediating Its Therapeutic Effects: A Review of Recent Studies. Mar Drugs 17(3).

17. Kim MJ, Jeon J, Lee JS (2014) Fucoidan prevents highfat diet-induced obesity in animals by suppression of fat accumulation. Phytother Res 28(1): 137-143.

18. Sudirman S, Ong AD, Chang HW, Kong ZL (2018) Effect of Fucoidan on Anterior Cruciate Ligament Transection and Medial Meniscectomy Induced Osteoarthritis in High-Fat Diet-Induced Obese Rats. Nutrients 10(6).

19. Oliveira RM, Câmara RBG, Monte JFS, Viana RLS, Melo KRT, et al. (2018) Commercial Fucoidans from Fucus vesiculosus Can Be Grouped into Antiadipogenic and Adipogenic Agents. Mar Drugs 16(6).

20. Catarino MD, Silva AMS, Mateus N, Cardoso SM (2019) Optimization of Phlorotannins Extraction from Fucus vesiculosus and Evaluation of Their Potential to Prevent Metabolic Disorders. Mar Drugs 17(3).

21. Catarino MD, Silva AMS, Cardoso SM (2017) Fucaceae: A Source of Bioactive Phlorotannins. Int J Mol Sci 18(6).

22. Sun S, Xu X, Sun X, Zhang X, Chen X, et al. (2019) Preparation and Identification of ACE Inhibitory
Peptides from the Marine Macroalga Ulva intestinalis. Mar Drugs 17(3).

23. Nagappan H, Pee PP, Kee SHY, Ow JT, Yan SW, et al. (2017) Malaysian brown seaweeds Sargassum siliquosum and Sargassum polycystum: Low density lipoprotein (LDL) oxidation, angiotensin converting enzyme (ACE), $\alpha$-amylase, and $\alpha$-glucosidase inhibition activities. Food Res Int 99(Pt2): 950-958.

24. Paiva L, Lima E, Neto AI, Baptista J (2017) Angiotensin I-Converting Enzyme (ACE) Inhibitory Activity, Antioxidant Properties, Phenolic Content and Amino Acid Profiles of Fucus spiralis L. Protein Hydrolysate Fractions. Mar Drugs 15(10).

25. Seca AML, Pinto DCGA (2018) Overview on the Antihypertensive and Anti-Obesity Effects of Secondary Metabolites from Seaweeds. Mar Drugs 16(7).

26. Pangestuti R, Kim SK (2017) Bioactive Peptide of Marine Origin for the Prevention and Treatment of Non-Communicable Diseases. Mar Drugs 15(3).

27. Collins KG, Fitzgerald GF, Stanton C, Ross RP (2016) Looking Beyond the Terrestrial: The Potential of Seaweed Derived Bioactives to Treat NonCommunicable Diseases. Mar Drugs 14(3).

28. Gomez Guzman M, Rodríguez Nogales A, Algieri F, Gálvez J (2018) Potential Role of Seaweed Polyphenols in Cardiovascular-Associated Disorders. Mar Drugs 16(8).

29. Majumder K, Wu J (2014) Molecular targets of antihypertensive peptides: understanding the mechanisms of action based on the pathophysiology of hypertension. Int J Mol Sci 16(1): 256-283.

30. Kammoun I, Ben Salah H, Ben Saad H, Cherif B, Droguet M, et al. (2018) Hypolipidemic and cardioprotective effects of Ulva lactuca ethanolic extract in hypercholesterolemic mice. Arch Physiol Biochem 124(4): 313-325.

31. Pengzhan Y, Ning L, Xiguang L, Gefei Z, Quanbin Z, et al. (2003) Antihyperlipidemic effects of different molecular weight sulfated polysaccharides from Ulva pertusa (Chlorophyta). Pharmacol Res 48(6): 543549.

32. Wang R, Paul VJ, Luesch H (2013) Seaweed extracts and unsaturated fatty acid constituents from the green alga Ulva lactuca as activators of the 


\section{Advances in Pharmacology and Clinical Trials}

cytoprotective Nrf2-ARE pathway. Free Radic Biol Med 57: 141-153.

33. Yu Y, Li Y, Du C, Mou H, Wang P (2017) Compositional and structural characteristics of sulfated polysaccharide from Enteromorpha prolifera. Carbohydr Polym 165: 221-228.

34. Sharifuddin Y, Chin YX, Lim PE, Phang SM (2015) Potential Bioactive Compounds from Seaweed for Diabetes Management. Mar Drugs 13(8): 5447-5491.

35. Tair ZI, Bensalah F, Boukortt F (2018) Effect of green alga Ulva lactuca polysaccharides supplementation on blood pressure and on atherogenic risk factors, in rats fed a high fat diet. Ann Cardiol Angeiol (Paris) 67(3): 133-140.

36. Lauritano C, Ianora A (2016) Marine Organisms with Anti-Diabetes Properties. Mar Drugs 14(12).

37. Mohapatra L, Bhattamishra SK, Panigrahy R, Parida S, Pati P (2016) Antidiabetic effect of Sargassum wightii and Ulva fasciata in high fat diet and multi low dose streptozotocin induced type 2 diabetic mice. UK J Pharm Biosci 4: 13-23.

38. Celikler S, Tas S, Vatan O, Ziyanok Ayvalik S, Yildiz G, et al. (2009) Anti-hyperglycemic and antigenotoxic potential of Ulva rigida ethanolic extract in the experimental diabetes mellitus. Food Chem Toxicol 47(8): 1837-1840.

39. Hassan S, El Twab SA, Hetta M, Mahmoud B (2011) Improvement of lipid profile and antioxidant of hypercholesterolemic albino rats by polysaccharides extracted from the green alga Ulva lactuca Linnaeus. Saudi J Biol Sci 18(4): 333-340.

40. BelHadj S, Hentati O, Elfeki A, Hamden K (2013) Inhibitory activities of Ulva lactuca polysaccharides on digestive enzymes related to diabetes and obesity. Arch Physiol Biochem 119(2): 81-87.

41. Bocanegra A, Bastida $S$, Benedí J, Nus M, Sánchez Montero JM, et al. (2009) Effect of seaweed and cholesterol-enriched diets on postprandial lipoproteinaemia in rats. Br J Nutr 102(12): 17281739.

42. Schultz Moreira AR, Olivero David R, Vázquez Velasco M, González Torres L, Benedí J, et al. (2014) Protective effects of sea spaghetti-enriched restructured pork against dietary cholesterol: effects on arylesterase and lipoprotein profile and composition of growing rats. J Med Food 17(8): 921928.

43. Nasir M, Saeidnia S, Mashinchian Moradi A, Gohari AR (2011) Sterols from the red algae, Gracilaria salicornia and Hypnea flagelliformis, from Persian Gulf. Pharmacogn Mag 7(26): 97-100.

44. Gabbia D, Dall'Acqua S, Di Gangi IM, Bogialli S, Caputi $\mathrm{V}$, et al. (2017) The Phytocomplex from Fucus vesiculosus and Ascophyllum nodosum Controls Postprandial Plasma Glucose Levels: An In Vitro and In Vivo Study in a Mouse Model of NASH. Mar Drugs 15(2).

45. Kim MS, Kim JY, Choi WH, Lee SS (2008) Effects of seaweed supplementation on blood glucose concentration, lipid profile, and antioxidant enzyme activities in patients with type 2 diabetes mellitus. Nutr Res Pract 2(2): 62-67.

46. Murray M, Dordevic AL, Ryan L, Bonham MP (2018) The Impact of a Single Dose of a Polyphenol-Rich Seaweed Extract on Postprandial Glycaemic Control in Healthy Adults: A Randomised Cross-Over Trial. Nutrients 10(3).

47. Tanemura $Y$, Yamanaka Okumura H, Sakuma M, Nii Y, Taketani Y, et al. (2014) Effects of the intake of Undaria pinnatifida (Wakame) and its sporophylls (Mekabu) on postprandial glucose and insulin metabolism. J Med Invest 61(3-4): 291-297.

48. Haskell Ramsay CF, Jackson PA, Dodd FL, Forster JS, Bérubé J, et al. (2018) Acute Post-Prandial Cognitive Effects of Brown Seaweed Extract in Humans. Nutrients 10(1).

49. Cherry P, O Hara C, Magee PJ, McSorley EM, Allsopp PJ (2019) Risks and benefits of consuming edible seaweeds. Nutr Rev 77(5): 307-329.

50. Gotama TL, Husni A, Ustadi (2018) Antidiabetic Activity of Sargassum hystrix Extracts in Streptozotocin-Induced Diabetic Rats. Prev Nutr Food Sci 23(3): 189-195.

51. Lee CW, Han JS (2012) Hypoglycemic Effect of Sargassum ringgoldianum Extract in STZ-induced Diabetic Mice. Prev Nutr Food Sci 17(1): 8-13.

52. Yang HW, Fernando KHN, Oh JY, Li X, Jeon YJ, et al. (2019) Anti-Obesity and Anti-Diabetic Effects of Ishige okamurae. Mar Drugs 17(4): 202. 


\section{Advances in Pharmacology and Clinical Trials}

53. Murray M, Dordevic AL, Ryan L, Bonham MP (2019) A Single-Dose of a Polyphenol-Rich Fucus Vesiculosus Extract is Insufficient to Blunt the Elevated Postprandial Blood Glucose Responses Exhibited by Healthy Adults in the Evening: A Randomised Crossover Trial. Antioxidants (Basel) 8(2): 49.

54. Coe S, Ryan L (2016) Impact of polyphenol-rich sources on acute postprandial glycaemia: a systematic review. J Nutr Sci 5: 1-11.

55. Murugan AC, Karim MR, Yusoff MB, Tan SH, Asras MF, et al. (2015) New insights into seaweed polyphenols on glucose homeostasis. Pharm Biol 53(8): 10871097.

56. Yang Z, Yin J, Wang Y, Wang J, Xia B, et al. (2019) The fucoidan A3 from the seaweed Ascophyllum nodosum enhances RCT-related genes expression in hyperlipidemic C57BL/6J mice. Int J Biol Macromol 134: 759-769.

57. Kamunde C, Sappal R, Melegy TM (2019) Brown seaweed (AquaArom) supplementation increases food intake and improves growth, antioxidant status and resistance to temperature stress in Atlantic salmon, Salmo salar. PLoS One 14(7).

58. Yang Z, Liu G, Wang Y, Yin J, Wang J, et al. (2019) Fucoidan A2 from the Brown Seaweed Ascophyllum nodosum Lowers Lipid by Improving Reverse Cholesterol Transport in C57BL/6J Mice Fed a HighFat Diet. J Agric Food Chem 67(20): 5782-5791.

59. Yone Y, Furuichi M, Urano K (1986) Effects of wakame Undaria pinnatifida and Ascophyllum nodosum on absorption of dietary nutrients, and blood sugar and plasma free amino-N levels of red sea bream. Nippon Suisan Gakkaishi 52(10): 1817-1819.

60. Dy Penaflorida V, Golez NV, Peikflorida VD, Golez NV (1996) Use of seaweed meals from Kappaphycus alvarezii and Gracilaria heteroclada as binders in diets for juvenile shrimp Penaeus monodon. Aquaculture 143(3-4): 393-401.

61. Nakagawa H (1997) Effect of dietary algae on improvement of lipid metabolism in fish. Biomed Pharmacother 51(8): 345-348.

62. Gille A, Stojnic B, Derwenskus F, Trautmann A, Schmid-Staiger U, et al. (2019) A Lipophilic Fucoxanthin-Rich Phaeodactylum tricornutum Extract Ameliorates Effects of Diet-Induced Obesity in C57BL/6J Mice. Nutrients 11(4): E796.
63. Jeon SM, Kim HJ, Woo MN, Lee MK, Shin YC, et al. (2010) Fucoxanthin-rich seaweed extract suppresses body weight gain and improves lipid metabolism in high-fat-fed C57BL/6J mice. Biotechnol J 5(9): 961969.

64. Chin YX, Mi Y, Cao WX, Lim PE, Xue CH, et al. (2019) A Pilot Study on Anti-Obesity Mechanisms of Kappaphycus Alvarezii: The Role of Native $\kappa$ Carrageenan and the Leftover Sans-Carrageenan Fraction. Nutrients 11(5): 1133.

65. Ha AW, Kim WK (2013) The effect of fucoxanthin rich power on the lipid metabolism in rats with a high fat diet. Nutr Res Pract 7(4): 287-293.

66. Patil NP, Le V, Sligar AD, Mei L, Chavarria D, et al. (2018) Algal Polysaccharides as Therapeutic Agents for Atherosclerosis. Front Cardiovasc Med 5:153.

67. Wan X, Li T, Liu D, Chen Y, Liu Y, et al. (2018) Effect of Marine Microalga Chlorella pyrenoidosa Ethanol Extract on Lipid Metabolism and Gut Microbiota Composition in High-Fat Diet-Fed Rats. Mar Drugs. 16(12): 498.

68. Li TT, Liu YY, Wan XZ, Huang ZR, Liu B, et al. (2018) Regulatory Efficacy of the Polyunsaturated Fatty Acids from Microalgae Spirulina platensis on Lipid Metabolism and Gut Microbiota in High-Fat Diet Rats. Int J Mol Sci 19(10): 3075.

69. Yin J, Wang J, Li F, Yang Z, Yang X, et al. (2019) The fucoidan from the brown seaweed Ascophyllum nodosum ameliorates atherosclerosis in apolipoprotein E-deficient mice. Food Funct 10(8): 5124-5139.

70. Shijo Y, Maruyama C, Nakamura E, Nakano R, Shima M, et al. (2019) Japan Diet Intake Changes Serum Phospholipid Fatty Acid Compositions in Middle-Aged Men: A Pilot Study. J Atheroscler Thromb 26(1): 3-13.

71. Zhao B, Cui Y, Fan X, Qi P, Liu C, et al. (2019) Antiobesity effects of Spirulina platensis protein hydrolysate by modulating brain-liver axis in high-fat diet fed mice. PLoS One 14(6).

72. Coue M, Tesse A, Falewee J, Aguesse A, Croyal M, et al. (2019) Spirulina Liquid Extract Protects against Fibrosis Related to Non-Alcoholic Steatohepatitis and Increases Ursodeoxycholic Acid. Nutrients 11(1): 194.

73. Huang H, Liao D, Pu R, Cui Y (2018) Quantifying the effects of spirulina supplementation on plasma lipid 


\section{Advances in Pharmacology and Clinical Trials}

and glucose concentrations, body weight, and blood pressure. Diabetes Metab Syndr Obes 11: 729-742.

74. Masuda K, Chitundu M (2019) Multiple micronutrient supplementation using spirulina platensis and infant growth, morbidity, and motor development: Evidence from a randomized trial in Zambia. PLoS One 14(2).

75. Hu J, Li Y, Pakpour S, Wang S, Pan Z, et al. (2019) Dose Effects of Orally Administered Spirulina Suspension on Colonic Microbiota in Healthy Mice. Front Cell Infect Microbiol 9: 243.

76. Hernandez-Lepe MA, Wall-Medrano A, Lopez-Diaz JA, Juarez-Oropeza MA, Hernandez-Torres RP, et al. (2019) Hypolipidemic Effect of Arthrospira (Spirulina) maxima Supplementation and a Systematic Physical Exercise Program in Overweight and Obese Men: A Double-Blind, Randomized, and Crossover Controlled Trial. Mar Drugs 17(5): 270.

77. Kim JY, Kwon YM, Kim IS, Kim JA, Yu DY, et al. (2018) Effects of the Brown Seaweed Laminaria japonica Supplementation on Serum Concentrations of IgG, Triglycerides, and Cholesterol, and Intestinal Microbiota Composition in Rats. Front Nutr 5: 23.

78. Barros-Gomes JAC, Nascimento DLA, Silveira ACR, Silva RK, Gomes DL, et al. (2018) In Vivo Evaluation of the Antioxidant Activity and Protective Action of the Seaweed Gracilaria birdiae. Oxid Med Cell Longev 2018: 1-12.

79. Lopez-Rios L, Vega T, Chirino R, Jung JC, Davis B, et al. (2018) Toxicological assessment of Xanthigen( $($ ) nutraceutical extract combination: Mutagenicity, genotoxicity and oral toxicity. Toxicol Rep 5: 10211031.

80. Wanyonyi S, du Preez R, Brown L, Paul NA, Panchal SK (2017) Kappaphycus alvarezii as a Food Supplement Prevents Diet-Induced Metabolic Syndrome in Rats. Nutrients 9(11): 1261.

81. Mikami N, Hosokawa M, Miyashita K, Sohma H, Ito YM, et al. (2017) Reduction of HbA1c levels by fucoxanthin-enriched akamoku oil possibly involves the thrifty allele of uncoupling protein 1 (UCP1): a randomised controlled trial in normal-weight and obese Japanese adults. J Nutr Sci 6: e5.

82. Seo YJ, Lee K, Chei S, Jeon YJ, Lee BY (2019) Ishige okamurae Extract Ameliorates the Hyperglycemia and Body Weight Gain of $\mathrm{db} / \mathrm{db}$ Mice through Regulation of the PI3K/Akt Pathway and
Thermogenic Factors by FGF21. Mar Drugs 17(7): 407.

83. Sakai C, Abe S, Kouzuki M, Shimohiro H, Ota Y, et al. (2019) A Randomized Placebo-controlled Trial of an Oral Preparation of High Molecular Weight Fucoidan in Patients with Type 2 Diabetes with Evaluation of Taste Sensitivity. Yonago Acta Med 62(1): 14-23.

84. Choi J, Kim KJ, Koh EJ, Lee BY (2018) Gelidium elegans Extract Ameliorates Type 2 Diabetes via Regulation of MAPK and PI3K/Akt Signaling. Nutrients 10(1): 51.

85. Maeda H, Fukuda S, Izumi H, Saga N (2018) AntiOxidant and Fucoxanthin Contents of Brown Alga Ishimozuku (Sphaerotrichia divaricata) from the West Coast of Aomori, Japan. Mar Drugs 16(8): 255.

86. McMacken M, Shah S (2017) A plant-based diet for the prevention and treatment of type 2 diabetes. J Geriatr Cardiol 14(5): 342-354.

87. Takahashi K, Kamada C, Yoshimura H, Okumura R, Iimuro S, et al. (2012) Effects of total and green vegetable intakes on glycated hemoglobin A1c and triglycerides in elderly patients with type 2 diabetes mellitus: the Japanese Elderly Intervention Trial. Geriatr Gerontol Int Suppl 1: 50-58.

88. Motshakeri M, Ebrahimi M, Goh YM, Matanjun P, Mohamed S (2013) Sargassum polycystum reduces hyperglycaemia, dyslipidaemia and oxidative stress via increasing insulin sensitivity in a rat model of type 2 diabetes. J Sci Food Agric 93(7): 1772-1778.

89. Motshakeri M, Ebrahimi M, Goh YM, Othman HH, Hair-Bejo M, et al. (2014) Effects of Brown Seaweed (Sargassum polycystum) Extracts on Kidney, Liver, and Pancreas of Type 2 Diabetic Rat Model. Evid Based Complement Alternat Med 2014: 379-407.

90. Johnson J (2018) what are the benefits of seaweed? Medical News Today.

91. Son M, Oh S, Lee HS, Ryu B, Jiang Y, et al. (2019) Pyrogallol-Phloroglucinol-6,6'-Bieckol from Ecklonia cava Improved Blood Circulation in Diet-Induced Obese and Diet-Induced Hypertension Mouse Models. Mar Drugs 17(5): 272.

92. Wada K, Nakamura K, Tamai Y, Tsuji M, Sahashi Y, et al. (2011) Seaweed intake and blood pressure levels in healthy pre-school Japanese children. Nutr J 10: 83. 


\section{Advances in Pharmacology and Clinical Trials}

93. Wells ML, Potin P, Craigie JS, Raven JA, Merchant SS, et al. (2017) Algae as nutritional and functional food sources: revisiting our understanding. J Appl Phycol 29(2): 949-982.

94. Gammone MA, Riccioni G, Parrinello G, D'Orazio N (2018) Omega-3 Polyunsaturated Fatty Acids: Benefits and Endpoints in Sport. Nutrients 11(1): 46.

95. Circuncisao AR, Catarino MD, Cardoso SM, Silva AMS (2016) Minerals from Macroalgae Origin: Health Benefits and Risks for Consumers. Mar Drugs 16(11): 400.

96. Martinez-Villaluenga C, Penas E, Rico D, Martin-Diana AB, Portillo MP, et al. (2018) Potential Usefulness of a Wakame/Carob Functional Snack for the Treatment of Several Aspects of Metabolic Syndrome: From in vitro to in vivo Studies. Mar Drugs 16(12): 512.

97. Jung IH, Kim SE, Lee YG, Kim DH, Kim H, et al. (2018) Antihypertensive Effect of Ethanolic Extract from Acanthopanax sessiliflorus Fruits and Quality Control of Active Compounds. Oxid Med Cell Longev 2018: 114.

98. Kawamura A, Kajiya K, Kishi H, Inagaki J, Mitarai M, et al. (2018) The Nutritional Characteristics of the Hypotensive WASHOKU-modified DASH Diet: A Subanalysis of the DASH-JUMP Study. Curr Hypertens Rev 14(1): 56-65.

99. Fitzgerald C, Aluko RE, Hossain M, Rai DK, Hayes M (2014) Potential of a renin inhibitory peptide from the red seaweed Palmaria palmata as a functional food ingredient following confirmation and characterization of a hypotensive effect in spontaneously hypertensive rats. J Agric Food Chem 62(33): 8352-8356.

100. Cardoso SM, Pereira OR, Seca AM, Pinto DC, Silva AM (2015) Seaweeds as Preventive Agents for Cardiovascular Diseases: From Nutrients to Functional Foods. Mar Drugs 13(11): 6838-6865.

101. Bleakley S, Hayes M (2017) Algal Proteins: Extraction, Application, and Challenges Concerning Production. Foods 6(5).

102. Sellimi S, Ksouda G, Benslima A, Nasri R, Rinaudo M, et al. (2017) Enhancing colour and oxidative stabilities of reduced-nitrite turkey meat sausages during refrigerated storage using fucoxanthin purified from the Tunisian seaweed Cystoseira barbata. Food Chem Toxicol 107(Pt B): 620-629.
103. Heo SJ, Jeon YJ (2009) Evaluation of diphlorethohydroxycarmalol isolated from Ishige okamurae for radical scavenging activity and its protective effect against H2O2-induced cell damage. Process Biochemistry 44(4): 412-418.

104. Heo SJ, Jeon YJ (2008) Radical scavenging capacity and cytoprotective effect of enzymatic digests of Ishige okamurae. Journal Applied Phycology 20: 1087-1095.

105. Kang MC, Lee SH, Lee WW, Kang N, Kim EA, et al. (2014) Protective effect of fucoxanthin isolated from Ishige okamurae against high-glucose induced oxidative stress in human umbilical vein endothelial cells and zebrafish model. Journal of Functional Foods 11: 304-312.

106. Ahn SM, Hong YK, Kwon GS, Sohn HY (2011) Evaluation of antioxidant and nitrite scavenging activity of seaweed extracts. J. Life Sci 21: 576-583.

107. Kang MC, Wijesinghe WA, Lee SH, Kang SM, Ko SC, et al. (2013) Dieckol isolated from brown seaweed Ecklonia cava attenuates type II diabetes in $\mathrm{db} / \mathrm{db}$ mouse model. Food Chem Toxicol 53: 294-298.

108. Lee SH, Park MH, Kang SM, Ko SC, Kang MC, et al. (2012) Dieckol isolated from Ecklonia cava protects against high-glucose induced damage to rat insulinoma cells by reducing oxidative stress and apoptosis. Biosci Biotechnol Biochem 76(8): 14451451.

109. Apostolidis E, Lee CM (2010) In vitro potential of Ascophyllum nodosum phenolic antioxidantmediated alpha-glucosidase and alpha-amylase inhibition. J Food Sci 75(3): H97-102.

110. Maeda $H$ (2015) Nutraceutical effects of fucoxanthin for obesity and diabetes therapy: a review. J Oleo Sci 64(2): 125-132.

111. Manandhar B, Paudel P, Seong SH, Jung HA, Choi JS (2019) Characterizing Eckol as a Therapeutic Aid: A Systematic Review. Mar Drugs 17(6).

112. Kumar MS (2019) Peptides and Peptidomimetics as Potential Antiobesity Agents: Overview of Current Status. Front Nutr 6: 11.

113. Sanjeewa KKA, Lee WW, Jeon YJ (2018) Nutrients and bioactive potentials of edible green and red seaweed in Korea. Fish Aquat Sci 21: 19. 


\section{Advances in Pharmacology and Clinical Trials}

114. Savini I, Catani MV, Evangelista D, Gasperi V, Avigliano L (2013) Obesity-associated oxidative stress: strategies finalized to improve redox state. Int J Mol Sci. 14(5): 10497-10538.

115. Gammone MA, D'Orazio N (2015) Anti-obesity activity of the marine carotenoid fucoxanthin. Mar Drugs 13(4): 2196-2214.

116. Maeda H, Kanno S, Kodate M, Hosokawa M, Miyashita K (2015) Fucoxanthinol, Metabolite of Fucoxanthin, Improves Obesity-Induced Inflammation in Adipocyte Cells. Mar Drugs 13(8): 4799-4813.

117. Catarino MD, Silva AMS, Cardoso SM (2018) Phycochemical Constituents and Biological Activities of Fucus spp. Mar Drugs 16(8).

118. Gammone MA, Riccioni G, D'Orazio N (2015) Marine Carotenoids against Oxidative Stress: Effects on Human Health. Mar Drugs 13(10): 6226-6246.

119. Mhadhebi L, Mhadhebi A, Robert J, Bouraoui A (2014) Antioxidant, Anti-inflammatory and Antiproliferative Effects of Aqueous Extracts of Three Mediterranean Brown Seaweeds of the Genus Cystoseira. Iran J Pharm Res 13(1): 207-220.

120. Kiokias S, Proestos C, Oreopoulou V (2018) Effect of Natural Food Antioxidants against LDL and DNA Oxidative Changes. Antioxidants (Basel) 7(10).

121. Siegel RL, Miller KD, Jemal A (2019) Cancer statistics, 2019. CA Cancer J Clin 69(1): 7-34.

122. Shah SC, Kayamba V, Peek RM Jr, Heimburger D (2019) Cancer Control in Low- and Middle-Income Countries: Is It Time to Consider Screening? J Glob Oncol 5: 1-8.

123. Ferlay J, Colombet M, Soerjomataram I, Mathers C, Parkin DM, et al. (2019) Estimating the global cancer incidence and mortality in 2018: GLOBOCAN sources and methods. Int J Cancer 144(8): 1941-1953.

124. Feng RM, Zong YN, Cao SM, Xu RH (2019) Current cancer situation in China: good or bad news from the 2018 Global Cancer Statistics? Cancer Commun (Lond) 39(1): 22.

125. WHO (2018) Latest global cancer data: Cancer burden rises to 18.1 million new cases and 9. 6 million cancer deaths in 2018, International Agency for Research on Cancer, World Health Organization, pp: 1-3.

126. Schüz J, Espina C, Wild CP (2019) Primary prevention: a need for concerted action. Mol Oncol 13(3): 567-578.

127. WHO (2018) Cancer. Health Topics.

128. AK Mohiuddin (2019) Non-drug pain management: opportunities to explore (e-book). Publisher: Biomed Grid LLC, USA.

129. WHO (2018) $\$ 46$ billion in productivity lost to cancer in major emerging economies, International Agency for Research on Cancer, World Health Organization, pp: 1-2.

130. World Cancer Day.

131. Olivares-Bañuelos $T$, Gutiérrez-Rodríguez AG, Méndez-Bellido R, Tovar-Miranda R, Arroyo-Helguera O, et al. (2019) Brown Seaweed Egregia menziesii's Cytotoxic Activity against Brain Cancer Cell Lines. Molecules 24(2).

132. Rocha DHA, Seca AML, Pinto DCGA (2018) Seaweed Secondary Metabolites In Vitro and In Vivo Anticancer Activity. Mar Drugs 16(11).

133. Cho M, Park GM, Kim SN, Amna T, Lee S, Shin WS (2014) Glioblastoma-specific anticancer activity of pheophorbide a from the edible red seaweed Grateloupia elliptica. J Microbiol Biotechnol 24(3): 346-353.

134. Park MN, Song HS, Kim M, Lee MJ, Cho W, et al. (2017) Review of Natural Product-Derived Compounds as Potent Antiglioblastoma Drugs. Biomed Res Int 2017: 8139848.

135. Florczyk SJ, Kievit FM, Wang K, Erickson AE, Ellenbogen RG, et al. (2016) 3D Porous ChitosanAlginate Scaffolds Promote Proliferation and Enrichment of Cancer Stem-Like Cells. J Mater Chem B 4(38): 6326-6334.

136. Kievit FM, Wang K, Erickson AE, Lan Levengood SK, Ellenbogen RG, et al. (2016) Modeling the tumor microenvironment using chitosan-alginate scaffolds to control the stem-like state of glioblastoma cells. Biomater Sci 4(4): 610-613.

137. Wang K, Kievit FM, Erickson AE, Silber JR, Ellenbogen RG, et al. (2016) Culture on 3D Chitosan- 


\section{Advances in Pharmacology and Clinical Trials}

Hyaluronic Acid Scaffolds Enhances Stem Cell Marker Expression and Drug Resistance in Human Glioblastoma Cancer Stem Cells. Adv Healthc Mater 5(24): 3173-3181.

138. Xiao W, Sohrabi A, Seidlits SK (2017) Integrating the glioblastoma microenvironment into engineered experimental models. Future Sci OA 3(3): FSO189.

139. Florczyk SJ, Wang K, Jana S, Wood DL, Sytsma SK, et al. (2013) Porous chitosan-hyaluronic acid scaffolds as a mimic of glioblastoma microenvironment ECM. Biomaterials 34(38): 10143-10150.

140. Palamà IE, D'Amone S, Cortese $B$ (2018) Microenvironmental Rigidity of 3D Scaffolds and Influence on Glioblastoma Cells: A Biomaterial Design Perspective. Front Bioeng Biotechnol 6: 131.

141. Wang K, Kievit FM, Florczyk SJ, Stephen ZR, Zhang M (2015) 3D Porous Chitosan-Alginate Scaffolds as an In Vitro Model for Evaluating Nanoparticle-Mediated Tumor Targeting and Gene Delivery to Prostate Cancer. Biomacromolecules 16(10): 3362-3372.

142. Musah-Eroje A, Watson S (2019) A novel 3D in vitro model of glioblastoma reveals resistance to temozolomide which was potentiated by hypoxia. J Neurooncol 142(2): 231-240.

143. Yang J, Li Y, Zhang T, Zhang X (2016) Development of bioactive materials for glioblastoma therapy. Bioact Mater 1(1): 29-38.

144. Wu HL, Fu XY, Cao WQ, Xiang WZ, Hou YJ, et al. (2019) Induction of Apoptosis in Human Glioma Cells by Fucoxanthin via Triggering of ROS-Mediated Oxidative Damage and Regulation of MAPKs and PI3K-AKT Pathways. J Agric Food Chem 67(8): 22122219.

145. Afzal S, Garg S, Ishida Y, Terao K, Kaul SC, Wadhwa R (2019) Rat Glioma Cell-Based Functional Characterization of Anti-Stress and Protein Deaggregation Activities in the Marine Carotenoids, Astaxanthin and Fucoxanthin. Mar Drugs 17(3).

146. Garg S, Afzal S, Elwakeel A, Sharma D, Radhakrishnan N, et al. (2019) Marine Carotenoid Fucoxanthin Possesses Anti-Metastasis Activity: Molecular Evidence. Mar Drugs 17(6).

147. Miao L, Chi S, Wu M, Liu Z, Li Y (2019) Deregulation of phytoene- $\beta$-carotene synthase results in derepression of astaxanthin synthesis at high glucose concentration in Phaffia rhodozyma astaxanthinoverproducing strain MK19. BMC Microbiol 19(1): 133.

148. Liu Y, Zheng J, Zhang Y, Wang Z, Yang Y, Bai M, Dai Y (2016) Fucoxanthin Activates Apoptosis via Inhibition of PI3K/Akt/mTOR Pathway and Suppresses Invasion and Migration by Restriction of p38-MMP-2/9 Pathway in Human Glioblastoma Cells. Neurochem Res 41(10): 2728-2751.

149. Zhang L, Wang H, Xu J, Zhu J, Ding K (2014) Inhibition of cathepsin $\mathrm{S}$ induces autophagy and apoptosis in human glioblastoma cell lines through ROS-mediated PI3K/AKT/mTOR/p70S6K and JNK signaling pathways. Toxicol Lett 228(3): 248-259.

150. Hormozi M, Ghoreishi S, Baharvand P (2019) Astaxanthin induces apoptosis and increases activity of antioxidant enzymes in LS-180 cells. Artificial Cells Nanomedicine Biotechnology 47(1): 891-895.

151. Lu DY, Chang CS, Yeh WL, Tang CH, Cheung CW, et al. (2012) The novel phloroglucinol derivative BFP induces apoptosis of glioma cancer through reactive oxygen species and endoplasmic reticulum stress pathways. Phytomedicine 19(12): 1093-1100.

152. Pinhatti AV, de Barros FM, de Farias CB, Schwartsmann G, Poser GL, et al. (2013) Antiproliferative activity of the dimeric phloroglucinol and benzophenone derivatives of Hypericum spp. native to southern Brazil. Anticancer Drugs 4(7): 699-703.

153. Jakobs D, Hage-Hülsmann A, Prenner L, Kolb C, Weiser D, et al. (2013) Downregulation of $\beta 1$ adrenergic receptors in rat $\mathrm{C} 6$ glioblastoma cells by hyperforin and hyperoside from St John's wort. J Pharm Pharmacol 65(6): 907-915.

154. Lai SW, Huang BR, Liu YS, Lin HY, Chen CC, et al. (2018) Differential Characterization of Temozolomide-Resistant Human Glioma Cells. Int J Mol Sci 19(1). 127.

155. Tsai CF, Yeh WL, Chen JH, Lin C, Huang SS, et al. (2014) Osthole suppresses the migratory ability of human glioblastoma multiforme cells via inhibition of focal adhesion kinase-mediated matrix metalloproteinase-13 expression. Int J Mol Sci 15(3): 3889-3903.

156. Alghazwi M, Smid S, Musgrave I, Zhang W (2019) In vitro studies of the neuroprotective activities of 


\section{Advances in Pharmacology and Clinical Trials}

astaxanthin and fucoxanthin against amyloid beta $(A \beta(1-42))$ toxicity and aggregation. Neurochem Int 124: 215-224.

157. Raposo MF, de Morais AM, de Morais RM (2015) Carotenoids from Marine Microalgae: A Valuable Natural Source for the Prevention of Chronic Diseases. Mar Drugs 13(8): 5128-5155.

158. Peng J, Yuan JP, Wu CF, Wang JH (2011) Fucoxanthin, a marine carotenoid present in brown seaweeds and diatoms: metabolism and bioactivities relevant to human health. Mar Drugs 9(10):18061828.

159. Hsu HY, Hwang PA (2019) Clinical applications of fucoidan in translational medicine for adjuvant cancer therapy. Clin Transl Med 8(1).

160. van Weelden G, Bobiński M, Okła K, van Weelden WJ, Romano A, et al. (2019) Fucoidan Structure and Activity in Relation to Anti-Cancer Mechanisms. Mar Drugs 17(1): 1-30.

161. Wang Y, Xing M, Cao Q, Ji A, Liang H, et al. (2019) Biological Activities of Fucoidan and the Factors Mediating Its Therapeutic Effects: A Review of Recent Studies. Mar Drugs 17(3): 1-18.

162. Misra P, Singh S (2019) Role of cytokines in combinatorial immunotherapeutics of non-small cell lung cancer through systems perspective. Cancer Med 8(5): 1976-1995.

163. Ercolano G, De Cicco P, Ianaro A (2019) New Drugs from the Sea: Pro-Apoptotic Activity of Sponges and Algae Derived Compounds. Mar Drugs 17(1). 1-31.

164. Erfani N, Nazemosadat Z, Moein M (2015) Cytotoxic activity of ten algae from the Persian Gulf and Oman Sea on human breast cancer cell lines; MDA-MB-231, MCF-7, and T-47D. Pharmacognosy Res 7(2):133-137.

165. Wu SY, Wu AT, Yuan KS, Liu SH (2016) Brown Seaweed Fucoidan Inhibits Cancer Progression by Dual Regulation of mir-29c/ADAM12 and miR-175p/PTEN Axes in Human Breast Cancer Cells. J Cancer. 7(15): 2408-2419.

166. Moussavou G, Kwak DH, Obiang-Obonou BW, Maranguy CA, Dinzouna-Boutamba SD, et al. (2014) Anticancer effects of different seaweeds on human colon and breast cancers. Mar Drugs 12(9): 48984911.
167. Montuori N, Pesapane A, Rossi FW, Giudice V, De Paulis A, et al. (2016) Urokinase type plasminogen activator receptor (UPAR) as a new therapeutic target in cancer. Transl Med UniSa 15:15-21.

168. Teas J, Vena S, Cone DL, Irhimeh M (2013) The consumption of seaweed as a protective factor in the etiology of breast cancer: proof of principle. J Appl Phycol 25(3): 771-779.

169. Shamsabadi FT, Khoddami A, Fard SG, Abdullah R, Othman HH, et al. (2013) Comparison of tamoxifen with edible seaweed (Eucheuma cottonii L.) extract in suppressing breast tumor. Nutr Cancer 65(2): 255-62.

170. Jazzara M, Ghannam A, Soukkarieh C, Murad H (2016) Anti-Proliferative Activity of $\lambda$-Carrageenan Through the Induction of Apoptosis in Human Breast Cancer Cells, Int J Cancer Manag 9(4):e3836.

171. Groult H, Cousin R, Chot-Plassot C, Maura M, Bridiau $N$, et al. (2019) $\lambda$-Carrageenan Oligosaccharides of Distinct Anti-Heparanase and Anticoagulant Activities Inhibit MDA-MB-231 Breast Cancer Cell Migration. Mar Drugs 17(3). 1-15.

172. Losada-Echeberría M, Herranz-López M, Micol V, Barrajón-Catalán E (2017) Polyphenols as Promising Drugs against Main Breast Cancer Signatures. Antioxidants (Basel) 6(4): 1-24.

173. Namvar F, Mohamad R, Baharara J, Zafar-Balanejad S, Fargahi F, et al. (2013) Antioxidant, antiproliferative, and antiangiogenesis effects of polyphenol-rich seaweed (Sargassum muticum). Biomed Res Int pp: 1-9.

174. Niedzwiecki A, Roomi MW, Kalinovsky T, Rath M (2016) Anticancer Efficacy of Polyphenols and Their Combinations. Nutrients. 8(9): 1-17.

175. Kapinova A, Kubatka P, Golubnitschaja O, Kello M, Zubor P, et al. (2018) Dietary phytochemicals in breast cancer research: anticancer effects and potential utility for effective chemoprevention. Environ Health Prev Med 23(1): 36.

176. Keating E, Martel F (2018) Antimetabolic Effects of Polyphenols in Breast Cancer Cells: Focus on Glucose Uptake and Metabolism. Front Nutr. Apr 16(5): 25.

177. Sudhakaran M, Sardesai S, Doseff AI (2019) Flavonoids: New Frontier for Immuno-Regulation and Breast Cancer Control. Antioxidants (Basel) 8(4). 


\section{Advances in Pharmacology and Clinical Trials}

178. Hui C, Qi X, Qianyong Z, Xiaoli P, Jundong Z, et al. (2013) Flavonoids, flavonoid subclasses and breast cancer risk: a meta-analysis of epidemiologic studies. PLoS One 8(1): e54318.

179. Sak K (2017) Epidemiological Evidences on Dietary Flavonoids and Breast Cancer Risk: A Narrative Review. Asian Pac J Cancer Prev 18(9): 2309-2328.

180. Takemura H, Sakakibara H, Yamazaki S, Shimoi K (2013) Breast cancer and flavonoids - a role in prevention. Curr Pharm Des 19(34): 6125-6132.

181. Batra P, Sharma AK (2013) Anti-cancer potential of flavonoids: recent trends and future perspectives. 3 Biotech 3(6): 439-459.

182. Magne Nde CB, Zingue S, Winter E, Creczynski-Pasa TB, Michel T, et al. (2015) Flavonoids, Breast Cancer Chemopreventive and/or Chemotherapeutic Agents. Curr Med Chem 22(30): 3434-3446.

183. Abotaleb M, Samuel SM, Varghese E, Varghese S, Kubatka P, et al. (2018) Flavonoids in Cancer and Apoptosis. Cancers (Basel) 11(1): 28.

184. Pang BB, Chu YK, Yang H (2018) [Anti-breast cancer mechanism of flavonoids]. Zhongguo Zhong Yao Za Zhi 43(5): 913-920.

185. Zhang HW, Hu JJ, Fu RQ Liu X, Zhang YH, et al. (2018) Flavonoids inhibit cell proliferation and induce apoptosis and autophagy through downregulation of $\mathrm{PI} 3 \mathrm{~K} \gamma$ mediated $\mathrm{PI} 3 \mathrm{~K} / \mathrm{AKT} / \mathrm{mTOR} / \mathrm{p} 70 \mathrm{S6K} / \mathrm{ULK}$ signaling pathway in human breast cancer cells. Sci Rep 8(1): 11255.

186. Rodríguez-García C, Sánchez-Quesada C, Gaforio JJ (2019) Dietary Flavonoids as Cancer Chemopreventive Agents: An Updated Review of Human Studies. Antioxidants (Basel) 8(5): 137.

187. Atashrazm F, Lowenthal RM, Woods GM, Holloway AF, Dickinson JL (2015) Fucoidan and cancer: a multifunctional molecule with anti-tumor potential. Mar Drugs 13(4): 2327-2346.

188. Lu J, Shi KK, Chen S, Wang J, Hassouna A, et al. (2018) Fucoidan Extracted from the New Zealand Undaria pinnatifida-Physicochemical Comparison against Five Other Fucoidans: Unique Low Molecular Weight Fraction Bioactivity in Breast Cancer Cell Lines. Mar Drugs 16(12): E461.
189. Zorofchian Moghadamtousi S, Karimian H, Khanabdali R, Razavi M, Firoozinia M, et al. (2014) Anticancer and antitumor potential of fucoidan and fucoxanthin, two main metabolites isolated from brown algae. Scientific World Journal pp: 10.

190. Xue M, Ge Y, Zhang J, Wang Q, Hou L, et al. (2012) Anticancer properties and mechanisms of fucoidan on mouse breast cancer in vitro and in vivo. PLoS One $7(8)$ : e43483.

191. Pawar VK, Singh Y, Sharma K, Shrivastav A, Sharma A, et al. (2019) Improved chemotherapy against breast cancer through immunotherapeutic activity of fucoidan decorated electrostatically assembled nanoparticles bearing doxorubicin. Int J Biol Macromol 122: 1100-1114.

192. He X, Xue M, Jiang S, Li W, Yu J, et al. (2019) Fucoidan Promotes Apoptosis and Inhibits EMT of Breast Cancer Cells. Biol Pharm Bull 42(3): 442-447.

193. Xue M, Ge Y, Zhang J, Liu Y, Wang Q et al. (2013) Fucoidan inhibited 4T1 mouse breast cancer cell growth in vivo and in vitro via downregulation of Wnt/ $\beta$-catenin signaling. Nutr Cancer 65(3): 460-468.

194. Xue M, Ji X, Liang H, Liu Y, Wang B, et al. (2018) The effect of fucoidan on intestinal flora and intestinal barrier function in rats with breast cancer. Food Funct 9(2): 1214-1223.

195. Oliveira C, Neves NM, Reis RL, Martins A, Silva TH (2018) Gemcitabine delivered by fucoidan/chitosan nanoparticles presents increased toxicity over human breast cancer cells. Nanomedicine (Lond). 13(16): 2037-2050.

196. Gong X, Smith JR, Swanson HM, Rubin LP (2018) Carotenoid Lutein Selectively Inhibits Breast Cancer Cell Growth and Potentiates the Effect of Chemotherapeutic Agents through ROS-Mediated Mechanisms. Molecules 23(4): E905.

197. Chang J, Zhang Y, Li Y, Lu K, Shen Y, et al. (2018) $\mathrm{NrF2/ARE}$ and NF- $\mathrm{KB}$ pathway regulation may be the mechanism for lutein inhibition of human breast cancer cell. Future Oncol 14(8): 719-726.

198. Mignone LI, Giovannucci E, Newcomb PA, TitusErnstoff L, Trentham-Dietz A, et al. (2009) Dietary carotenoids and the risk of invasive breast cancer. Int J Cancer 124(12): 2929-2937. 


\section{Advances in Pharmacology and Clinical Trials}

199. Li Y, Zhang Y, Liu X, Wang M, Wang P, et al. (2018) Lutein inhibits proliferation, invasion and migration of hypoxic breast cancer cells via downregulation of HES1. Int J Oncol 52(6): 2119-2129.

200. Yan B, Lu MS, Wang L, Mo XF, Luo WP, et al. (2016) Specific serum carotenoids are inversely associated with breast cancer risk among Chinese women: a case-control study. Br J Nutr 115(1): 129-137.

201. Li YX, Himaya SW, Dewapriya P, Zhang C, Kim SK (2013) Fumigaclavine C from a marine-derived fungus Aspergillus fumigatus induces apoptosis in MCF-7 breast cancer cells. Mar Drugs 11(12): 50635086.

202. Dyshlovoy SA, Honecker F (2015) Marine Compounds and Cancer: Where Do We Stand? Mar Drugs 13(9): 5657-5665.

203. Vaikundamoorthy R, Krishnamoorthy V, Vilwanathan R, Rajendran R (2018) Structural characterization and anticancer activity (MCF7 and MDA-MB-231) of polysaccharides fractionated from brown seaweed Sargassum wightii. Int J Biol Macromol 111: 1229-1237.

204. Boopathy NS, Kathiresan K (2010) Anticancer drugs from marine flora: an overview. J Oncol 2010: 214186.

205. Abd-Ellatef GF, Ahmed OM, Abdel-Reheim ES, AbdelHamid AZ (2017) Ulva lactuca polysaccharides prevent Wistar rat breast carcinogenesis through the augmentation of apoptosis, enhancement of antioxidant defense system, and suppression of inflammation. Breast Cancer 9: 67-83.

206. Fedorov SN, Ermakova SP, Zvyagintseva TN, Stonik VA (2013) Anticancer and cancer preventive properties of marine polysaccharides: some results and prospects. Mar Drugs 11(12): 4876-4901.

207. Ghannam A, Murad H, Jazzara M, Odeh A, Allaf AW (2018) Isolation, Structural characterization, and antiproliferative activity of phycocolloids from the red seaweed Laurencia papillosa on MCF-7 human breast cancer cells. Int J Biol Macromol 108: 916-926.

208. Vishchuk OS, Ermakova SP, Zvyagintseva TN (2011) Sulfated polysaccharides from brown seaweeds Saccharina japonica and Undaria pinnatifida: isolation, structural characteristics, and antitumor activity. Carbohydr Res 346(17): 2769-2776.
209. Vaseghi G, Sharifi M, Dana N, Ghasemi A, Yegdaneh A (2018) Cytotoxicity of Sargassum angustifolium Partitions against Breast and Cervical Cancer Cell Lines. Adv Biomed Res 7: 43.

210. Kim EK, Tang Y, Kim YS, Hwang JW, Choi EJ, et al. (2015) First evidence that Ecklonia cava-derived dieckol attenuates MCF-7 human breast carcinoma cell migration. Mar Drugs 13(4): 1785-1797.

211. Hashiguchi Y, Muro K, Saito Y, Ito Y, Ajioka Y, et al. (2019) Japanese Society for Cancer of the Colon and Rectum (JSCCR) guidelines 2019 for the treatment of colorectal cancer. Int J Clin Oncol: 1-42.

212. Recio-Boiles A, Waheed A, Cagir B (2019) Cancer, Colon. In: StatPearls Publishing, Treasure Island.

213. Thanikachalam K, Khan G (2019) Colorectal Cancer and Nutrition. Nutrients 11(1): 164.

214. Vieira AR, Abar L, Chan DSM, Vingeliene S, Polemiti E, et al. (2017) Foods and beverages and colorectal cancer risk: a systematic review and meta-analysis of cohort studies, an update of the evidence of the WCRF-AICR Continuous Update Project. Ann Oncol 28(8): 1788-1802.

215. Kim J, Lee J, Oh JH, Chang HJ, Sohn DK, et al. (2019) Associations among dietary seaweed intake, c-MYC rs6983267 polymorphism, and risk of colorectal cancer in a Korean population: a case-control study. Eur J Nutr: 1-12.

216. Zhao Y, Zheng Y, Wang J, Ma S, Yu Y, et al. (2018) Fucoidan Extracted from Undaria pinnatifida: Source for Nutraceuticals/Functional Foods. Mar Drugs 16(9): 321.

217. Tsai HL, Tai CJ, Huang CW, Chang FR, Wang JY (2017) Efficacy of Low-Molecular-Weight Fucoidan as a Supplemental Therapy in Metastatic Colorectal Cancer Patients: A Double-Blind Randomized Controlled Trial. Mar Drugs 15(4): 122.

218. Wang SK, Li Y, White WL, Lu J (2014) Extracts from New Zealand Undaria pinnatifida Containing Fucoxanthin as Potential Functional Biomaterials against Cancer in Vitro. J Funct Biomater 5(2): 29-42.

219. Han YS, Lee JH, Lee SH (2015) Fucoidan inhibits the migration and proliferation of HT-29 human colon cancer cells via the phosphoinositide-3 kinase/Akt/mechanistic target of rapamycin pathways. Mol Med Rep 12(3): 3446-3452. 


\section{Advances in Pharmacology and Clinical Trials}

220. Han YS, Lee JH, Lee SH (2015) Antitumor Effects of Fucoidan on Human Colon Cancer Cells via Activation of Akt Signaling. Biomol Ther 23(3): 225-232.

221. Chen LM, Liu PY, Chen YA, Tseng HY, Shen PC, et al. (2017) Oligo-Fucoidan prevents IL-6 and CCL2 production and cooperates with p53 to suppress ATM signaling and tumor progression. Sci Rep 7(1): 11864.

222. Kim SK, Karagozlu MZ (2011) Chapter 17-Marine algae: Natural Product Source for the gastrointestinal Cancer Treatment. Advances in Food and Nutrition Research 64: 225-233.

223. Bakunina I, Chadova O, Malyarenko O, Ermakova S (2018) The Effect of Fucoidan from the Brown Alga Fucus evanescence on the Activity of $\alpha-\mathrm{N}$ Acetylgalactosaminidase of Human Colon Carcinoma Cells. Mar Drugs 16(5): 155.

224. Kim IH, Kwon MJ, Nam TJ (2017) Differences in cell death and cell cycle following fucoidan treatment in high-density HT-29 colon cancer cells. Mol Med Rep 15(6): 4116-4122.

225. Kim HY, Kim YM, Hong S (2019) Astaxanthin suppresses the metastasis of colon cancer by inhibiting the MYC-mediated downregulation of microRNA-29a-3p and microRNA-200a. Sci Rep 9(1): 9457.

226. Nagendraprabhu P, Sudhandiran G (2011) Astaxanthin inhibits tumor invasion by decreasing extracellular matrix production and induces apoptosis in experimental rat colon carcinogenesis by modulating the expressions of ERK-2, NFkB and COX2. Invest New Drugs 29(2): 207-224.

227. Yasui Y, Hosokawa M, Mikami N, Miyashita K, Tanaka T (2011) Dietary astaxanthin inhibits colitis and colitis-associated colon carcinogenesis in mice via modulation of the inflammatory cytokines. Chem Biol Interact 193(1): 79-87.

228. Liu X, Song M, Gao Z, Cai X, Dixon W, et al. (2016) Stereoisomers of Astaxanthin Inhibit Human Colon Cancer Cell Growth by Inducing G2/M Cell Cycle Arrest and Apoptosis. J Agric Food Chem 64(41): 7750-7759.

229. Wayakanon K, Rueangyotchanthana K, Wayakanon P, Suwannachart C (2018) The inhibition of Caco-2 proliferation by astaxanthin from Xanthophyllomyces dendrorhous. J Med Microbiol 67(4): 507-513.
230. Tanaka T, Kawamori T, Ohnishi M, Makita H, Mori H, et al. (1995) Suppression of azoxymethane-induced rat colon carcinogenesis by dietary administration of naturally occurring xanthophylls astaxanthin and canthaxanthin during the postinitiation phase. Carcinogenesis 16(12): 2957-2963.

231. Terasaki M, Iida T, Kikuchi F, Tamura K, Endo T, et al. (2019) Fucoxanthin potentiates anoikis in colon mucosa and prevents carcinogenesis in AOM/DSS model mice. J Nutr Biochem 64: 198-205.

232. Terasaki M, Masaka S, Fukada C, Houzaki M, Endo T, et al. (2019) Salivary Glycine Is a Significant Predictor for the Attenuation of Polyp and Tumor Microenvironment Formation by Fucoxanthin in AOM/DSS Mice. In Vivo 33(2): 365-374.

233. Terasaki M, Matsumoto N, Hashimoto R, Endo T, Maeda H, et al. (2019) Fucoxanthin administration delays occurrence of tumors in xenograft mice by colonospheres, with an anti-tumor predictor of glycine. J Clin Biochem Nutr 64(1): 52-58.

234. Das SK, Hashimoto T, Shimizu K, Yoshida T, Sakai T, et al. (2005) Fucoxanthin induces cell cycle arrest at G0/G1 phase in human colon carcinoma cells through up-regulation of p21WAF1/Cip1. Biochim Biophys Acta 1726(3): 328-335.

235. Hosokawa M, Kudo M, Maeda H, Kohno H, Tanaka T, et al. (2004) Fucoxanthin induces apoptosis and enhances the antiproliferative effect of the PPARgamma ligand, troglitazone, on colon cancer cells. Biochim Biophys Acta 1675(1-3): 113-119.

236. Kim JM, Araki S, Kim DJ, Park CB, Takasuka N, et al. (1998) Chemopreventive effects of carotenoids and curcumins on mouse colon carcinogenesis after 1,2dimethylhydrazine initiation. Carcinogenesis 9(1): 81-85.

237. Konishi I, Hosokawa M, Sashima T, Kobayashi H, Miyashita K (2006) Halocynthiaxanthin and fucoxanthinol isolated from Halocynthia roretzi induce apoptosis in human leukemia, breast and colon cancer cells. Comp Biochem Physiol C Toxicol Pharmacol 142(1-2): 53-59.

238. Kim J, Lee J, Oh JH, Chang HJ, Sohn DK, et al. (2019) Dietary Lutein Plus Zeaxanthin Intake and DICER1 rs3742330 A > G Polymorphism Relative to Colorectal Cancer Risk. Sci Rep 9(1): 3406. 


\section{Advances in Pharmacology and Clinical Trials}

239. Reynoso-Camacho R, González-Jasso E, FerrizMartínez R, Villalón-Corona B, Loarca-Piña GF, et al. (2011) Dietary supplementation of lutein reduces colon carcinogenesis in DMH-treated rats by modulating K-ras, $\mathrm{PKB}$, and $\beta$-catenin proteins. Nutr Cancer 63(1): 39-45.

240. Grudzinski W, Piet M, Luchowski R, Reszczynska E, Welc R, et al. (2018) Different molecular organization of two carotenoids, lutein and zeaxanthin, in human colon epithelial cells and colon adenocarcinoma cells. Spectrochim Acta A Mol Biomol Spectrosc 188: 57-63.

241. Kohler LN, Harris RB, Oren E, Roe DJ, Lance P, et al. (2018) Adherence to Nutrition and Physical Activity Cancer Prevention Guidelines and Development of Colorectal Adenoma. Nutrients 10(8): 1098.

242. Wang ZJ, Ohnaka K, Morita M, Toyomura K, Kono S, et al. (2013) Dietary polyphenols and colorectal cancer risk: the Fukuoka colorectal cancer study. World J Gastroenterol 19(17): 2683-2690.

243. Alam MN, Almoyad M, Huq F (2018) Polyphenols in Colorectal Cancer: Current State of Knowledge including Clinical Trials and Molecular Mechanism of Action. Biomed Res Int 2018: 4154185.

244. Murphy N, Achaintre D, Zamora-Ros R, Jenab M, Boutron-Ruault MC, et al. (2018) A prospective evaluation of plasma polyphenol levels and colon cancer risk. Int J Cancer 143(7): 1620-1631.

245. Mileo AM, Nisticò P, Miccadei S (2019) Polyphenols: Immunomodulatory and Therapeutic Implication in Colorectal Cancer. Front Immunol 10: 729.

246. Zamora-Ros R, Cayssials V, Jenab M, Rothwell JA, Fedirko V, et al. (2018) Dietary intake of total polyphenol and polyphenol classes and the risk of colorectal cancer in the European Prospective Investigation into Cancer and Nutrition (EPIC) cohort. Eur J Epidemiol 33(11): 1063-1075.

247. van der Veen DJ, Döpp CME, Siemonsma PC, Nijhuisvan der Sanden MWG, de Swart BJM, et al. (2019) Factors influencing the implementation of HomeBased Stroke Rehabilitation: Professionals' perspective. PLoS One 14(7): 0220226.

248. Galasso C, Orefice I, Pellone P, Cirino P, Miele R, et al. (2018) On the Neuroprotective Role of Astaxanthin: New Perspectives? Mar Drugs 16(8): 247.
249. Deng X, Wang M, Hu S, Feng Y, Shao Y, et al. (2019) The Neuroprotective Effect of Astaxanthin on Pilocarpine-Induced Status Epilepticus in Rats. Front Cell Neurosci 13: 123.

250. Grimmig B, Kim SH, Nash K, Bickford PC, Douglas Shytle R (2017) Neuroprotective mechanisms of astaxanthin: a potential therapeutic role in preserving cognitive function in age and neurodegeneration. Geroscience 39(1): 19-32.

251. Alghazwi M, Smid S, Zhang W (2018) In vitro protective activity of South Australian marine sponge and macroalgae extracts against amyloid beta $(\mathrm{A} \beta(1-$ 42)) induced neurotoxicity in PC-12 cells. Neurotoxicol Teratol 68: 72-83.

252. Cho KS, Shin M, Kim S, Lee SB (2018) Recent Advances in Studies on the Therapeutic Potential of Dietary Carotenoids in Neurodegenerative Diseases. Oxid Med Cell Longev 16: 4120458.

253. Grimmig B, Daly L, Subbarayan M, Hudson C, Williamson R, et al. (2017) Astaxanthin is neuroprotective in an aged mouse model of Parkinson's disease. Oncotarget 9(12): 10388-10401.

254. Sathasivam R, Ki JS (2018) A Review of the Biological Activities of Microalgal Carotenoids and Their Potential Use in Healthcare and Cosmetic Industries. Mar Drugs 16(1): 26.

255. Bahonar A, Saadatnia M, Khorvash F, Maracy M, Khosravi A (2017) Carotenoids as Potential Antioxidant Agents in Stroke Prevention: A Systematic Review. Int J Prev Med 8: 70.

256. Olasehinde TA, Olaniran AO, Okoh AI (2017) Therapeutic Potentials of Microalgae in the Treatment of Alzheimer's Disease. Molecules. 22(3)pii: E480.

257. Wu H, Niu H, Shao A, Wu C, Dixon BJ, Zhang J, et al. (2015) Astaxanthin as a Potential Neuroprotective Agent for Neurological Diseases. Mar Drugs 13(9): 5750-5766.

258. Barros MP, Poppe SC, Bondan EF (2014) Neuroprotective properties of the marine carotenoid astaxanthin and omega- 3 fatty acids, and perspectives for the natural combination of both in krill oil. Nutrients 6(3): 1293-1317.

259. Wen X, Huang A, Hu J, Zhong Z, Liu Y, et al. (2015) Neuroprotective effect of astaxanthin against 


\section{Advances in Pharmacology and Clinical Trials}

glutamate-induced cytotoxicity in HT22 cells: Involvement of the Akt/GSK-3 $\beta$ pathway. Neuroscience 303: 558-568.

260. Ito N, Saito H, Seki S, Ueda F, Asada T (2018) Effects of Composite Supplement Containing Astaxanthin and Sesamin on Cognitive Functions in People with Mild Cognitive Impairment: A Randomized, Double-Blind, Placebo-Controlled Trial. J Alzheimers Dis 62(4): 1767-1775.

261. Yamagishi R, Aihara M (2014) Neuroprotective effect of astaxanthin against rat retinal ganglion cell death under various stresses that induce apoptosis and necrosis. Mol Vis 20: 1796-1805.

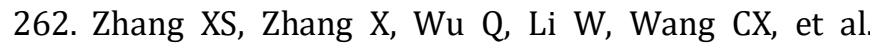
(2014) Astaxanthin offers neuroprotection and reduces neuroinflammation in experimental subarachnoid hemorrhage. J Surg Res 192(1): 206213.

263. Zhang XS, Zhang X, Zhou ML, Zhou XM, Li N, et al. (2014) Amelioration of oxidative stress and protection against early brain injury by astaxanthin after experimental subarachnoid hemorrhage. J Neurosurg 121(1): 42-54.

264. Yu J, Lin JJ, Yu R, He S, Wang QW, et al. (2017) Fucoxanthin prevents $\mathrm{H}(2) \mathrm{O}(2)$-induced neuronal apoptosis via concurrently activating the PI3-K/Akt cascade and inhibiting the ERK pathway. Food Nutr Res 61(1): 1304678.

265. Zhang L, Wang H, Fan Y, Gao Y, Li X, et al. (2017) Fucoxanthin provides neuroprotection in models of traumatic brain injury via the Nrf2-ARE and Nrf2autophagy pathways. Sci Rep 7: 46763.

266. Lin J, Yu J, Zhao J, Zhang K, Zheng J, et al. (2017) Fucoxanthin, a Marine Carotenoid, Attenuates $\beta$ Amyloid Oligomer-Induced Neurotoxicity Possibly via Regulating the PI3K/Akt and the ERK Pathways in SH-SY5Y Cells. Oxid Med Cell Longev 2017: 6792543.

267. Barbosa M, Valentão P, Andrade PB (2014) Bioactive compounds from macroalgae in the new millennium: implications for neurodegenerative diseases. Mar Drugs 12(9): 4934-4972.

268. Giacoppo S, Galuppo M, Montaut S, Iori R, Rollin P, et al. (2015) An overview on neuroprotective effects of isothiocyanates for the treatment of neurodegenerative diseases. Fitoterapia 106: 12-21.
269. Barbalace MC, Malaguti M, Giusti L, Lucacchini A, Hrelia S, et al. (2019) Anti-Inflammatory Activities of Marine Algae in Neurodegenerative Diseases. Int J Mol Sci 20(12) pii: E3061.

270. Lim CS, Jin DQ, Sung JY, Lee JH, Choi HG, et al. (2006) Antioxidant and anti-inflammatory activities of the methanolic extract of Neorhodomela aculeate in hippocampal and microglial cells. Biol Pharm Bull 29(6): 1212-1216.

271. Kang SM, Cha SH, Ko JY, Kang MC, Kim D, et al. (2012) Neuroprotective effects of phlorotannins isolated from a brown alga, Ecklonia cava, against H202-induced oxidative stress in murine hippocampal HT22 cells. Environ Toxicol Pharmacol 34(1): 96-105.

272. Kim JH, Lee NS, Jeong YG, Lee JH, Kim EJ, et al. (2012) Protective efficacy of an Ecklonia cava extract used to treat transient focal ischemia of the rat brain. Anat Cell Biol 45(2): 103-113.

273. Lee S, Youn K, Kim DH, Ahn MR, Yoon E, et al. (2018) Anti-Neuroinflammatory Property of Phlorotannins from Ecklonia cava on $A \beta(25-35)$-Induced Damage in PC12 Cells. Mar Drugs 17(1): 7.

274. Park SK, Kang JY, Kim JM, Park SH, Kwon BS, et al. (2018) Protective Effect of Fucoidan Extract from Ecklonia cava on Hydrogen Peroxide-Induced Neurotoxicity. J Microbiol Biotechnol 28(1): 40-49.

275. Cui Y, Amarsanaa K, Lee JH, Rhim JK, Kwon JM, et al. (2019) Neuroprotective mechanisms of dieckol against glutamate toxicity through reactive oxygen species scavenging and nuclear factor-like 2 /heme oxygenase-1 pathway. Korean J Physiol Pharmacol 23(2): 121-130.

276. Reid SNS, Ryu JK, Kim Y, Jeon BH (2018) The Effects of Fermented Laminaria japonica on Short-Term Working Memory and Physical Fitness in the Elderly. Evid Based Complement Alternat Med 2018: 8109621.

277. Reid SNS, Ryu JK, Kim Y, Jeon BH (2018) GABAenriched fermented Laminaria japonica improves cognitive impairment and neuroplasticity in scopolamine- and ethanol-induced dementia model mice. Nutr Res Pract 12(3): 199-207.

278. Wang J, Zhang Q, Zhang Z, Li Z (2008) Antioxidant activity of sulfated polysaccharide fractions extracted 


\section{Advances in Pharmacology and Clinical Trials}

from Laminaria japonica. Int J Biol Macromol 42(2): 127-132.

279. Wang J, Liu H, Jin W, Zhang H, Zhang Q (2016) Structure-activity relationship of sulfated hetero/galactofucan polysaccharides on dopaminergic neuron. Int J Biol Macromol 82: 878883.

280. Wang J, Liu H, Zhang X, Li X, Geng L, et al. (2017) Sulfated Hetero-Polysaccharides Protect SH-SY5Y Cells from $\mathrm{H}_{2} \mathrm{O}_{2}$-Induced Apoptosis by Affecting the PI3K/Akt Signaling Pathway. Mar Drugs 15(4): 110.

281. Zhang L, Hao J, Zheng Y, Su R, Liao Y, et al. (2018) Fucoidan Protects Dopaminergic Neurons by Enhancing the Mitochondrial Function in a Rotenoneinduced Rat Model of Parkinson's Disease. Aging Dis 9(4): 590-604.

282. Alghazwi M, Smid S, Karpiniec S, Zhang W (2019) Comparative study on neuroprotective activities of fucoidans from Fucus vesiculosus and Undaria pinnatifida. Int J Biol Macromol 122: 255-264.

283. Silva J, Alves C, Pinteus S, Mendes S, Pedrosa R (2018) Neuroprotective effects of seaweeds against 6-hydroxidopamine-induced cell death on an in vitro human neuroblastoma model. BMC Complement Altern Med 18(1): 58.

284. Jhamandas JH, Wie MB, Harris K, MacTavish D, Kar S (2005) Fucoidan inhibits cellular and neurotoxic effects of beta-amyloid (A beta) in rat cholinergic basal forebrain neurons. Eur J Neurosci 21(10): 26492659.

285. Kim S-K, Pangestuti R (2013) Prospects and potential application of seaweeds as neuroprotective agents. In: Se-Kwon Kim. Marine Nutraceuticals: Prospects and Perspectives. Publisher: CRC Press, ISBN 1466513527, 9781466513525.

286. Dewapriya P, Kim SK (2015) Marine Algae for Protecting Your Brain: Neuroprotective Potentials of Marine Algae. In: Se-Kwon Kim, Katarzyna Chojnacka. Marine Algae Extracts, 2 Volume Set: Processes, Products, and Applications. Publisher: John Wiley \& Sons, ISBN 3527337083, 9783527337088.

287. Burchell SR, Iniaghe LO, Zhang JH, Tang J. Fucoidan from Fucus vesiculosus Fails to Improve Outcomes Following Intracerebral Hemorrhage in Mice. In: Richard L. Applegate, Gang Chen, Hua Feng, John H. Zhang. Brain Edema XVI: Translate Basic Science into
Clinical Practice Volume 121 of Acta Neurochirurgica Supplement, Publisher: Springer, 2015 ISBN 3319184970, 9783319184975

288. Yende SR, Harle UN, Chaugule BB. Therapeutic potential and health benefits of Sargassum species. Pharmacogn Rev 8(15): 1-7.

289. Pinteus S, Lemos MFL, Silva J, Alves C, Neugebauer A, et al. (2017) An Insight into Sargassum muticum Cytoprotective Mechanisms against Oxidative Stress on a Human Cell In Vitro Model. Mar Drugs 15(11): 353.

290. Bogie J, Hoeks C, Schepers M, Tiane A, Cuypers A, et al. (2019) Dietary Sargassum fusiforme improves memory and reduces amyloid plaque load in an Alzheimer's disease mouse model. Sci Rep 9(1): 4908.

291. Zhao D, Zheng L, Qi L, Wang S, Guan L, et al. (2016) Structural Features and Potent Antidepressant Effects of Total Sterols and $\beta$-sitosterol Extracted from Sargassum horneri. Mar Drugs 14(7): 123.

292. Jin W, Liu B, Li S, Chen J, Tang H, et al. (2018) The structural features of the sulfated heteropolysaccharide (ST-1) from Sargassum thunbergii and its neuroprotective activities. Int J Biol Macromol 108: 307-313.

293. Huang CY, Kuo CH, Chen PW (2017) CompressionalPuffing Pretreatment Enhances Neuroprotective Effects of Fucoidans from the Brown Seaweed Sargassum hemiphyllum on 6-HydroxydopamineInduced Apoptosis in SH-SY5Y Cells. Molecules 23(1): 78.

294. Jin W, Zhang W, Wang J, Yao J, Xie E, et al. (2014) A study of neuroprotective and antioxidant activities of heteropolysaccharides from six Sargassum species. Int J Biol Macromol 336-42.

295. Jin W, Zhang W, Wang J, Zhang Q (2013) The neuroprotective activities and antioxidant activities of the polysaccharides from Saccharina japonica. Int J Biol Macromol 58: 240-244.

296. Torres MD, Flórez-Fernández N, Domínguez H (2019) Integral Utilization of Red Seaweed for Bioactive Production. Mar Drugs 17(6): 314.

297. Jin DQ, Lim CS, Sung JY, Choi HG, Ha I, et al. (2006) Ulva conglobata, a marine algae, has neuroprotective and anti-inflammatory effects in murine hippocampal and microglial cells. Neurosci Lett 402(1-2): 154-158. 


\section{Advances in Pharmacology and Clinical Trials}

298. Suganthy N, Karutha Pandian S, Pandima Devi K (2010) Neuroprotective effect of seaweeds inhabiting South Indian coastal area (Hare Island, Gulf of Mannar Marine Biosphere Reserve): Cholinesterase inhibitory effect of Hypnea valentiae and Ulva reticulata. Neurosci Lett 468(3): 216-219.

299. Ratnayake R, Liu Y, Paul VJ, Luesch H (2013) Cultivated sea lettuce is a multiorgan protector from oxidative and inflammatory stress by enhancing the endogenous antioxidant defense system. Cancer Prev Res (Phila) 6(9): 989-999.

300. Ning C, Wang HD, Gao R, Chang YC, Hu F, et al. (2018) Marine-derived protein kinase inhibitors for neuroinflammatory diseases. Biomed Eng Online 17(1): 46.

301. Wang J, Zheng J, Huang C, Zhao J, Lin J, et al. (2018) Eckmaxol, a Phlorotannin Extracted from Ecklonia maxima, Produces Anti- $\beta$-amyloid Oligomer Neuroprotective Effects Possibly via Directly Acting on Glycogen Synthase Kinase $3 \beta$. ACS Chem Neurosci $9(6): 1349-1356$.

302. Zhou X, Yi M, Ding L, He S, Yan X (2019) Isolation and Purification of a Neuroprotective Phlorotannin from the Marine Algae Ecklonia maxima by Size Exclusion and High-Speed Counter-Current Chromatography. Mar Drugs 17(4): E212.

303. Rengasamy RRK, Mutalib AA, Ashwell RN, Wendy AS, Johannes VS (2013) Acetylcholinesterase inhibitory activity of phlorotannins isolated from the brown alga, Ecklonia maxima (Osbeck) Papenfuss. Food Research International 54(1): 1250-1254.

304. Olasehinde TA, Olaniran AO, Okoh AI. Aqueousethanol extracts of some South African seaweeds inhibit beta-amyloid aggregation, cholinesterases, and beta-secretase activities in vitro. J Food Biochem 43(7): e12870.

305. Souza RB, Frota AF, Sousa RS, Cezario NA, Santos TB, et al. (2017) Neuroprotective Effects of Sulphated Agaran from Marine Alga Gracilaria cornea in Rat 6Hydroxydopamine Parkinson's Disease Model: Behavioural, Neurochemical and Transcriptional Alterations. Basic Clin Pharmacol Toxicol 120(2): 159-170.

306. Liu T, Tang X, Jia X, Wu X, Huang M, et al. (2019) The complete plastid genome and phylogenetic analysis of
Gracilaria edulis. Mitochondrial DNA Part B 4(2): 2598-2599.

307. Yang JI, Yeh CC, Lee JC, Yi SC, Huang HW, et al. (2012) Aqueous extracts of the edible Gracilaria tenuistipitata are protective against $\mathrm{H}_{2} \mathrm{O}_{2}$-induced DNA damage, growth inhibition, and cell cycle arrest. Molecules 17(6): 7241-7254.

308. Natarajan S, Shanmugiahthevar KP, Kasi PD (2009) Cholinesterase inhibitors from Sargassum and Gracilaria gracilis: seaweeds inhabiting South Indian coastal areas (Hare Island, Gulf of Mannar). Nat Prod Res 23(4): 355-369.

309. Ghannadi A, Plubrukarn A, Zandi K, Sartavi K, Yegdaneh A (2013) Screening for antimalarial and acetylcholinesterase inhibitory activities of some Iranian seaweeds. Res Pharm Sci 8(2): 113-118.

310. Andriani Y, Syamsumir DF, Yee TC, Harisson FS, Herng GM, et al. (2016) Biological Activities of Isolated Compounds from Three Edible Malaysian Red Seaweeds, Gracilaria changii, G. manilaensis and Gracilaria sp. Nat Prod Commun11(8): 1117-1120.

311. Ghannadi A, Shabani L, Yegdaneh A (2016) Cytotoxic, antioxidant and phytochemical analysis of Gracilaria species from Persian Gulf. Adv Biomed Res 5: 139.

312. Olasehinde TA, Olaniran AO, Okoh AI (2019) Phenolic composition, antioxidant activity, anticholinesterase potential and modulatory effects of aqueous extracts of some seaweeds on $\beta$-amyloid aggregation and disaggregation. Pharm Biol 57(1): 460-469.

313. Hannan MA, Mohibbullah M, Hong YK, Nam JH, Moon IS (2014) Gelidium amansii promotes dendritic spine morphology and synaptogenesis, and modulates NMDA receptor-mediated postsynaptic current. In Vitro Cell Dev Biol Anim 50(5): 445-452.

314. Linares AF, Loikkanen J, Jorge MF, Soria RB, Novoa AV (2004) Antioxidant and neuroprotective activity of the extract from the seaweed, Halimeda incrassata (Ellis) Lamouroux, against in vitro and in vivo toxicity induced by methyl-mercury. Vet Hum Toxicol 46(1): 1-5.

315. Fallarero A, Loikkanen JJ, Männistö PT, Castañeda O, Vidal A (2003) Effects of aqueous extracts of Halimeda incrassata (Ellis) Lamouroux and Bryothamnion triquetrum (S.G.Gmelim) Howe on 


\section{Advances in Pharmacology and Clinical Trials}

hydrogen peroxide and methyl mercury-induced oxidative stress in GT1-7 mouse hypothalamic immortalized cells. Phytomedicine 10(1): 39-47.

316. Fallarero A, Peltoketo A, Loikkanen J, Tammela P, Vidal A, et al. (2006) Effects of the aqueous extract of Bryothamnion triquetrum on chemical hypoxia and aglycemia-induced damage in GT1-7 mouse hypothalamic immortalized cells. Phytomedicine 13(4): 240-245.

317. Cavalcante-Silva LH, da Matta CB, de Araújo MV, Barbosa-Filho JM, de Lira DP ( de Oliveira Santos BV, de Miranda GE, Alexandre-Moreira MS. Antinociceptive and anti-inflammatory activities of crude methanolic extract of red alga Bryothamnion triquetrum. Mar Drugs 10(9): 1977-1992.

318. Sánchez-Lamar Á, González-Pumariega M, FuentesLeón F, Vernhes Tamayo M, Schuch AP (2017) Evaluation of Genotoxic and DNA Photo-Protective Activity of Bryothamnion triquetrum and Halimeda incrassata Seaweeds Extracts. Cosmetics 4: 23.

319. Liu J, Banskota AH, Critchley AT, Hafting J, Prithiviraj B (2015) Neuroprotective effects of the cultivated Chondrus crispus in a C. elegans model of Parkinson's disease. Mar Drugs 13(4): 2250-2266.

320. Sangha JS, Wally O, Banskota AH, Stefanova R, Hafting JT, et al. (2015) A Cultivated Form of a Red Seaweed (Chondrus crispus), Suppresses $\beta$-AmyloidInduced Paralysis in Caenorhabditis elegans. Mar Drugs 13(10): 6407-6424.

321. Oh JH, Choi JS, Nam TJ (2018) Fucosterol from an Edible Brown Alga Ecklonia stolonifera Prevents Soluble Amyloid Beta-Induced Cognitive Dysfunction in Aging Rats. Mar Drugs 16(10): E368.

322. Yoon NY, Lee SH, Yong L, Kim SK (2009) Phlorotannins from Ishige okamurae and their acetyland butyrylcholinesterase inhibitory effects. J Funct Foods 1: 331-335.

323. Dev K, Maurya R (2017) Chapter 7. Marine Derived Anti-Alzheimer's Agents of Promise. In: Goutam Brahmachari. Neuroprotective Natural Products: Clinical Aspects and Mode of Action. John Wiley \& Sons.

324. Tuppin P, Rivière $S$, Deutsch D, Gastaldi-Menager C, Sabaté JM (2019) Burden of drug use for gastrointestinal symptoms and functional gastrointestinal disorders in France: a national study using reimbursement data for 57 million inhabitants. Therap Adv Gastroenterol 12: 1756284819853790.

325. Peery AF, Crockett SD, Murphy CC, Lund JL, Dellon ES, et al. (2018) Burden and Cost of Gastrointestinal, Liver, and Pancreatic Diseases in the United States: Update 2018. Gastroenterology 156(1): 254-272.e11.

326. Hu PJ (2015) Inflammatory Bowel Disease in Asia: The Challenges and Opportunities. Intest Res 13(3): 188-190.

327. Werlang ME, Palmer WC, Lacy BE (2019) Irritable Bowel Syndrome and Dietary Interventions. Gastroenterol Hepatol (N Y) 15(1): 16-26.

328. AK Mohiuddin (2019) Complimentary Treatments for Minor GI Disorders. Adv Pharmacol Clin Trials 4(1): 000153.

329. Leung AK, Hon KL (2019) Gastroesophageal reflux in children: an updated review. Drugs Context 8: 212591.

330. Brun R, Kuo B (2010) Functional dyspepsia. Therap Adv Gastroenterol 3(3): 145-164.

331. Savarino E, de Bortoli N, Zentilin P, Martinucci I, Bruzzone L, et al. (2012) Alginate controls heartburn in patients with erosive and nonerosive reflux disease. World J Gastroenterol 18(32): 4371-4378.

332. Bharucha AE, Camilleri M, Veil E, Burton D, Zinsmeister AR (2013) Comprehensive assessment of gastric emptying with a stable isotope breath test. Neurogastroenterol Motil 25(1): e60-e69.

333. Bharucha AE, Kudva Y, Basu A, Camilleri M, Low PA, et al. (2014) Relationship between glycemic control and gastric emptying in poorly controlled type 2 diabetes. Clin Gastroenterol Hepatol 13(3): 466-476.

334. Ko SJ, Bu Y, Bae J, Bang YM, Kim J, et al. (2014) Protective effect of Laminaria japonica with probiotics on murine colitis. Mediators Inflamm 2014: 417814.

335. Jing Y, Liu H, Xu W, Yang Q (2017) Amelioration of the DSS-induced colitis in mice by pretreatment with 4,4'-diaponeurosporene-producing Bacillus subtilis. Exp Ther Med 14(6): 6069-6073.

336. Sudirman S, Hsu YH, He JL, Kong ZL (2018) Dietary polysaccharide-rich extract from Eucheuma cottonii modulates the inflammatory response and 


\section{Advances in Pharmacology and Clinical Trials}

suppresses colonic injury on dextran sulfate sodiuminduced colitis in mice. PLoS One 13(10): e0205252.

337. Wardani G, Farida N, Andayani R, Kuntoro M, Sudjarwo SA (2017) The Potency of Red Seaweed (Eucheuma cottonii) Extracts as Hepatoprotector on Lead Acetate-induced Hepatotoxicity in Mice. Pharmacognosy Res 9(3): 282-286.

338. Xu SS, Liu QM, Xiao AF, Maleki SJ, Alcocer M, et al. (2017) Eucheuma cottonii Sulfated Oligosaccharides Decrease Food Allergic Responses in Animal Models by Up-regulating Regulatory $\mathrm{T}$ (Treg) Cells. J Agric Food Chem 65(15): 3212-3222.

339. Peng J, Zheng TT, Li X, Liang Y, Wang LJ, et al. (2019) Plant-Derived Alkaloids: The Promising DiseaseModifying Agents for Inflammatory Bowel Disease. Front Pharmacol 10: 351.

340. Carneiro JG, Holanda TBL, Quinderé ALG, Frota AF, Soares VVM, et al. (2018) Gastroprotective Effects of Sulphated Polysaccharides from the Alga Caulerpa mexicana Reducing Ethanol-Induced Gastric Damage. Pharmaceuticals (Basel) 11(1): E6.

341. Hernández-Muñoz R, Montiel-Ruíz C, VázquezMartínez $O$ (2000) Gastric mucosal cell proliferation in ethanol-induced chronic mucosal injury is related to oxidative stress and lipid peroxidation in rats. Lab Invest 80(8):1161-1169.

342. V Brito T, Barros FCN, Silva RO, Dias Júnior GJ, C Júnior JS, et al. (2016) Sulfated polysaccharide from the marine algae Hypnea musciformis inhibits TNBSinduced intestinal damage in rats. Carbohydr Polym 151: 957-964.

343. Lean QY, Eri RD, Fitton JH, Patel RP, Gueven N (2015) Fucoidan Extracts Ameliorate Acute Colitis. PLoS One 10(6): e0128453.

344. Nie Y, Lin Q, Luo F (2017) Effects of Non-Starch Polysaccharides on Inflammatory Bowel Disease. Int J Mol Sci 18(7): E1372.

345. Ryan MT, O'Shea CJ, Collins CB, O'Doherty JV, Sweeney T (2012) Effects of dietary supplementation with Laminaria hyperborea, Laminaria digitata, and Saccharomyces cerevisiae on the IL-17 pathway in the porcine colon. J Anim Sci 90(Suppl 4):263-265.

346. Shimazu T, Borjigin L, Katoh $\mathrm{K}$, Roh SG, Kitazawa H, et al. (2019) Addition of Wakame seaweed (Undaria pinnatifida) stalk to animal feed enhances immune response and improves intestinal microflora in pigs. Anim Sci J 90(9):1248-1260.

347. O'Sullivan L, Murphy B, McLoughlin P, Duggan P, Lawlor PG, et al. (2010) Prebiotics from marine macroalgae for human and animal health applications. Mar Drugs 8(7): 2038-2064.

348. Jha R, Fouhse JM, Tiwari UP, Li L, Willing BP (2019) Dietary Fiber and Intestinal Health of Monogastric Animals. Front Vet Sci 6: 48.

349. de Jesus Raposo MF, de Morais AM, de Morais RM (2016) Emergent Sources of Prebiotics: Seaweeds and Microalgae. Mar Drugs 14(2): E27.

350. Ko SJ, Kim J, Han G, Kim SK, Kim HG, et al. (2014) Laminaria japonica combined with probiotics improves intestinal microbiota: a randomized clinical trial. J Med Food 17(1):76-82.

351. Shahid MA, Sharma S (2019) Physiology, Thyroid Hormone. StatPearls.

352. Combet E, Ma ZF, Cousins F, Thompson B, Lean ME (2014) Low-level seaweed supplementation improves iodine status in iodine-insufficient women. Br J Nutr 112(5): 753-761.

353. Bajaj JK, Salwan P, Salwan S (2016) Various Possible Toxicants Involved in Thyroid Dysfunction: A Review. J Clin Diagn Res 10(1): FE01- FE03.

354. Farebrother J, Zimmermann MB, Andersson $M$ (2019) Excess iodine intake: sources, assessment, and effects on thyroid function. Ann N Y Acad Sci 1446(1): 44-65.

355. Wang C, Yatsuya H, Li Y, Ota A, Tamakoshi K, et al. (2016) Prospective study of seaweed consumption and thyroid cancer incidence in women: the Japan collaborative cohort study. Eur J Cancer Prev 25(3): 239-245.

356. Chen A, Kim SS, Chung E, Dietrich KN (2013) Thyroid hormones in relation to lead, mercury, and cadmium exposure in the National Health and Nutrition Examination Survey, 2007-2008. Environ Health Perspect 121(2): 181-186.

357. Buha A, Matovic V, Antonijevic B, Bulat Z, Curcic M, et al. (2018) Overview of Cadmium Thyroid Disrupting Effects and Mechanisms. Int J Mol Sci 19(5): E1501. 


\section{Advances in Pharmacology and Clinical Trials}

358. Nie X, Chen Y, Chen Y, Chen C, Han B, et al. (2017) Lead and cadmium exposure, higher thyroid antibodies and thyroid dysfunction in Chinese women. Environ Pollut 230: 320-328.

359. Yorita Christensen KL (2013) Metals in blood and urine, and thyroid function among adults in the United States 2007-2008. Int J Hyg Environ Health 216(6): 624-632.

360. Zava TT, Zava DT (2011) Assessment of Japanese iodine intake based on seaweed consumption in Japan: A literature-based analysis. Thyroid Res 4: 14.

361. Myers SP, Mulder AM, Baker DG, Robinson SR, Rolfe MI, et al. (2016) Effects of fucoidan from Fucus vesiculosus in reducing symptoms of osteoarthritis: a randomized placebo-controlled trial. Biologics 10: 8188.

362. Myers SP, O'Connor J, Fitton JH, Brooks L, Rolfe M, et al. (2010) A combined phase I and II open label study on the effects of a seaweed extract nutrient complex on osteoarthritis. Biologics 4: 33-44.

363. Brown ES, Allsopp PJ, Magee PJ, Gill CI, Nitecki S, et al. (2014) Seaweed and human health. Nutr Rev 72(3): 205-216.

364. Cardoso LCP, Pinto NB, Nobre MEP, Silva MR, Pires $\mathrm{GM}$, et al. (2019) Anti-inflammatory and antinociceptive effects of phonophoresis in animal models: a randomized experimental study. Braz J Med Biol Res 52(2): e7773.

365. Bhatia S, Sharma K, Sharma A, Nagpal K, Bera T (2015) Anti-inflammatory, Analgesic and Antiulcer properties of Porphyra vietnamensis. Avicenna J Phytomed 5(1): 69-77.

366. Bhatia S, Sardana S, Senwar KR, Dhillon A, Sharma A, et al. (2019) In vitro antioxidant and antinociceptive properties of Porphyra vietnamensis. Biomedicine (Taipei) 9(1): 3 .

367. Zakaria A, Jais MR, Ishak R (2018) Analgesic Properties of Nigella Sativa and Eucheuma Cottonii Extracts. J Nat Sci Biol Med 9(1):23-26.

368. Vázquez AI, Sánchez CM, Delgado NG, Alfonso AM, Ortega YS, et al. (2011) Anti-inflammatory and analgesic activities of red seaweed Dichotomaria obtusata. Braz J Pharm Sci 47: 111-118.
369. Abdelhamid A, Jouini M, Bel Haj Amor H, Mzoughi Z, Dridi M, et al. (2018) Phytochemical Analysis and Evaluation of the Antioxidant, Anti-Inflammatory, and Antinociceptive Potential of Phlorotannin-Rich Fractions from Three Mediterranean Brown Seaweeds. Mar Biotechnol (NY) 20(1): 60-74.

370. Kim S, Choi SI, Kim GH, Imm JY (2019) AntiInflammatory Effect of Ecklonia cava Extract on Porphyromonas gingivalis LipopolysaccharideStimulated Macrophages and a Periodontitis Rat Model. Nutrients 11(5): E1143.

371. Ha JW, Song H, Hong SS, Boo YC (2019) Marine Alga Ecklonia cava Extract and Dieckol Attenuate Prostaglandin E(2) Production in HaCaT Keratinocytes Exposed to Airborne Particulate Matter. Antioxidants (Basel) 8(6): E190.

372. Kim JG, Lim DW, Cho S, Han D, Kim YT (2014) The edible brown seaweed Ecklonia cava reduces hypersensitivity in postoperative and neuropathic pain models in rats. Molecules. 19(6): 7669-778.

373. de Souza ET, de Lira DP, de Queiroz AC, da Silva DJ, de Aquino AB, et al. (2009) The antinociceptive and anti-inflammatory activities of caulerpin, a bisindole alkaloid isolated from seaweeds of the genus Caulerpa. Mar Drugs 7(4): 689-704.

374. Shih CC, Hwang HR, Chang CI, Su HM, Chen PC, et al. (2017) Anti-Inflammatory and Antinociceptive Effects of Ethyl Acetate Fraction of an Edible Red Macroalgae Sarcodia ceylanica. Int J Mol Sci 18(11): E2437.

375. Sayed AA, Sadek SA, Solimán AM, Marzouk M (2017) PROSPECTIVE EFFECT OF RED ALGAE, ACTINOTRICHIA FRAGILIS, AGAINST SOME OSTEOARTHRITIS AETIOLOGY. Afr J Tradit Complement Altern Med 14(1): 231-241.

376. Albuquerque IR, Cordeiro SL, Gomes DL, Dreyfuss JL, Filgueira LG, et al. (2013) Evaluation of antinociceptive and anti-inflammatory activities of a heterofucan from Dictyota menstrualis. Mar Drugs 11(8): 2722-2740.

377. Coura CO, de Araújo IW, Vanderlei ES, Rodrigues JA, Quinderé AL, et al. (2012) Antinociceptive and antiinflammatory activities of sulphated polysaccharides from the red seaweed Gracilaria cornea. Basic Clin Pharmacol Toxicol 110(4): 335-341. 


\section{Advances in Pharmacology and Clinical Trials}

378. de Sousa Oliveira Vanderlei E, de Araújo IW, Quinderé AL, Fontes BP, Eloy YR, et al. (2011) The involvement of the HO-1 pathway in the antiinflammatory action of a sulfated polysaccharide isolated from the red seaweed Gracilaria birdiae. Inflamm Res 60(12): 1121-1130.

379. Florez N, Gonzalez-Munoz MJ, Ribeiro D, Fernandes E, Dominguez H, et al. (2017) Algae Polysaccharides' Chemical Characterization and their Role in the Inflammatory Process. Curr Med Chem 24(2): 149175.

380. Wang L, Wang X, Wu H, Liu R (2014) Overview on biological activities and molecular characteristics of sulfated polysaccharides from marine green algae in recent years. Mar Drugs 12(9): 4984-5020.

381. da Conceição Rivanor RL, Chaves HV, do Val DR, de Freitas AR, Lemos JC, et al. (2014) A lectin from the green seaweed Caulerpa cupressoides reduces mechanical hyper-nociception and inflammation in the rat temporomandibular joint during zymosaninduced arthritis. Int Immunopharmacol 21(1): 3443.

382. Margret RJ, Kumaresan S, Ravikumar SA (2009) preliminary study on the anti-inflammatory activity of methanol extract of Ulva lactuca in rat. J Environ Biol 30(5 Suppl): 899-902.

383. Neelakandan Y, Venkatesan A (2016) Antinociceptive and anti-inflammatory effect of sulfated polysaccharide fractions from Sargassum wightii and Halophila ovalis in male Wistar rats. Indian J Pharmacol 48(5): 562-570.

384. Kim DH, Kim ME, Lee JS (2015) Inhibitory effects of extract from G. lanceolata on LPS-induced production of nitric oxide and IL-1 $\beta$ via down-regulation of MAPK in macrophages. Appl Biochem Biotechnol 175(2): 657-665.

385. Kang JY, Khan MN, Park NH, Cho JY, Lee MC, et al. (2008) Antipyretic, analgesic, and anti-inflammatory activities of the seaweed Sargassum fulvellum and Sargassum thunbergii in mice. J Ethnopharmacol 116(1): 187-190.

386. Lin YY, Lin SC, Feng CW, Chen PC, Su YD, et al. (2015) Anti-Inflammatory and Analgesic Effects of the Marine-Derived Compound Excavatolide B Isolated from the Culture-Type Formosan Gorgonian Briareum excavatum. Mar Drugs 13(5): 2559-2579.
387. Ribeiro NA, Abreu TM, Chaves HV, Bezerra MM, Monteiro HS, et al. (2014) Sulfated polysaccharides isolated from the green seaweed Caulerpa racemosa plays antinociceptive and anti-inflammatory activities in a way dependent on HO-1 pathway activation. Inflamm Res 63(7): 569-80.

388. Hwang PA, Hung YL, Chien SY (2015) Inhibitory activity of Sargassum hemiphyllum sulfated polysaccharide in arachidonic acid-induced animal models of inflammation. J Food Drug Anal 23(1): 4956.

389. Lajili S, Deghrigue M, Bel Haj Amor H, Muller CD, Bouraoui A (2016) In vitro immunomodulatory activity and in vivo anti-inflammatory and analgesic potential with gastroprotective effect of the Mediterranean red alga Laurencia obtusa. Pharm Biol 54(11): 2486-2495.

390. Matta CBB, Cavalcante-Silva LHA, Araújo-Júnior JX, Miranda GEC, Bastos KX, et al. (2015) Antinociceptive and Anti-inflammatory Effects of Caulerpa kempfii (Caulerpaceae). Rev Virtual Quim 7(2): 730-743.

391. Rodrigues JA, Vanderlei ES, Silva LM, Araújo IW, Queiroz IN, et al. (2012) Antinociceptive and antiinflammatory activities of a sulfated polysaccharide isolated from the green seaweed Caulerpa cupressoides. Pharmacol Rep 64(2): 282-292.

392. Frost I, Van Boeckel TP, Pires J, Craig J, Laxminarayan R (2019) Global Geographic Trends in Antimicrobial Resistance: The Role of International Travel. J Travel Med, pp: taz036.

393. Dixit A, Kumar N, Kumar S, Trigun V (2019) Antimicrobial Resistance: Progress in the Decade since Emergence of New Delhi Metallo- $\beta$-Lactamase in India. Indian J Community Med 44(1): 4-8.

394. Lu WJ, Lin HJ, Hsu PH, Lai M, Chiu JY, et al. (2019) Brown and Red Seaweeds Serve as Potential Efflux Pump Inhibitors for Drug-Resistant Escherichia coli. Evid Based Complement Alternat Med 2019:1836982.

395. Alves C, Silva J, Pinteus S, Gaspar H, Alpoim MC, et al. (2018) From Marine Origin to Therapeutics: The Antitumor Potential of Marine Algae-Derived Compounds. Front Pharmacol 9: 777.

396. Besednova N, Zaporozhets T, Kuznetsova T, Makarenkova I, Fedyanina L, et al. (2019) Metabolites of Seaweeds as Potential Agents for the Prevention 


\section{Advances in Pharmacology and Clinical Trials}

and Therapy of Influenza Infection. Mar Drugs 17(6): 373.

397. Pérez MJ, Falqué E, Domínguez H (2016) Antimicrobial Action of Compounds from Marine Seaweed. Mar Drugs 14(3): E52.

398. Walsh PJ, McGrath S, McKelvey S, Ford L, Sheldrake G, et al. (2019) The Osteogenic Potential of Brown Seaweed Extracts. Mar Drugs 17(3): E141.

399. Jacobsen C, Sørensen AM, Holdt SL, Akoh CC, Hermund DB (2019) Source, Extraction, Characterization, and Applications of Novel Antioxidants from Seaweed. Annu Rev Food Sci Technol 10: 541-568.

400. Chakraborty K, Dhara S (2019) First report of substituted 2H-pyranoids from brown seaweed Turbinaria conoides with antioxidant and antiinflammatory activities. Nat Prod Resn 5: 1-11.

401. Farasat M, Khavari-Nejad RA, Nabavi SM, Namjooyan F (2014) Antioxidant Activity, Total Phenolics and Flavonoid Contents of some Edible Green Seaweeds from Northern Coasts of the Persian Gulf. Iran J Pharm Res 13(1): 163-170.

402. Silva J, Alves C, Freitas R, Martins A, Pinteus S, et al. (2019) Antioxidant and Neuroprotective Potential of the Brown Seaweed Bifurcaria bifurcata in an in vitro Parkinson's Disease Model. Mar Drugs 17(2): E85.

403. Cho SH, Kang SE, Cho JY, Kim AR, Park SM, et al. (2007) The antioxidant properties of brown seaweed (Sargassum siliquastrum) extracts. J Med Food 10(3): 479-485.

404. Pinteus S, Silva J, Alves C, Horta A, Fino N, et al. (2017) Cytoprotective effect of seaweeds with high antioxidant activity from the Peniche coast (Portugal). Food Chem 218: 591-599.

405. Sivagnanam SP, Yin S, Choi JH, Park YB, Woo HC, et al. (2015) Biological Properties of Fucoxanthin in Oil Recovered from Two Brown Seaweeds Using Supercritical CO2 Extraction. Mar Drugs 13(6): 34223442.

406. Saravana PS, Cho YJ, Park YB, Woo HC, Chun BS (2016) Structural, antioxidant, and emulsifying activities of fucoidan from Saccharina japonica using pressurized liquid extraction. Carbohydr Polym 153: 518-525.
407. Athiperumalsami T, Rajeswari VD, Poorna SH, Kumar V, Jesudass LL (2010) Antioxidant activity of seagrasses and seaweeds. Bot Mar 53: 251-257.

408. Kar K, Sahoo SS, Kar B, Naik SK, Panda PC (2019) Antioxidant Activity Of Halophila Ovalis And Halophila Beccarii (Hydrocharitaceae): Two Important Seagrass Species Of Chilika Lagoon, India". Asian Journal of Pharmaceutical and Clinical Research 12(3): 136-140.

409. Ammar HH, Hafsa J, Le Cerf D, Bouraoui A, Majdoub H (2016) Antioxidant and gastroprotective activities of polysaccharides from the Tunisian brown algae (Cystoseira sedoides). Journal of the Tunisian Chemical Societypp: 80 -88.

410. Mhadhebi L, Laroche-Clary A, Robert J, Bouraoui A (2011) Antioxidant, anti-inflammatory, and antiproliferative activities of organic fractions from the Mediterranean brown seaweed Cystoseira sedoides. Can J Physiol Pharmacol 89(12): 911-921.

411. Murugan K, Iyer VV (2013) Differential growth inhibition of cancer cell lines and antioxidant activity of extracts of red, brown, and green marine algae. In Vitro Cell Dev Biol Anim 49(5): 324-334.

412. Lee JW, Seok JK, Boo YC (2018) Ecklonia cava Extract and Dieckol Attenuate Cellular Lipid Peroxidation in Keratinocytes Exposed to PM10. Evid Based Complement Alternat Med 2018: 8248323.

413. Athukorala Y, Kim KN, Jeon YJ (2006) Antiproliferative and antioxidant properties of an enzymatic hydrolysate from brown alga, Ecklonia cava. Food Chem Toxicol 44(7): 1065-1074.

414. Dong X, Bai Y, Xu Z, Shi Y, Sun Y, et al. (2019) Phlorotannins from Undaria pinnatifida Sporophyll: Extraction, Antioxidant, and Anti-Inflammatory Activities. Mar Drugs 17(8): E434.

415. Mesripour A, Rabian N, Yegdaneh A (2019) The effect of different partitions of seaweed Sargassum plagyophylum on depression behavior in mice model of despair. J Complement Integr Med

416. Farmer MA, Leja A, Foxen-Craft E, Chan L, MacIntyre LC, et al. (2014) Pain reduces sexual motivation in female but not male mice. J Neurosci 34(17): 574753.

417. Mahadevan K (2018) Seaweeds: a sustainable food source, In: Sirpa Sarlio. Towards Healthy and 


\section{Advances in Pharmacology and Clinical Trials}

Sustainable Diets: Perspectives and Policy to Promote the Health of People and the Planet. Springer Briefs in Public Health

418. Roby Jose Ciju (2019) Seaweeds as Vegetables, AGRIHORTICO.

419. Philippines. Ministry of Natural Resources (1986) Guide to Philippine Flora and Fauna. Natural Resources Manegement Center, University of the Philippines.

420. Liu X, Wang S, Cao S, He X, Qin L, et al. (2018) Structural Characteristics and Anticoagulant Property In Vitro and In Vivo of a Seaweed Sulfated Rhamnan. Mar Drugs 16(7): E243.

421. Adrien A, Bonnet A, Dufour D, Baudouin S, Maugard T, et al. (2019) Anticoagulant Activity of Sulfated Ulvan Isolated from the Green Macroalga Ulva rigida. Mar Drugs 117(5): E291.

422. Mendes Marques ML, Presa FB, Viana RLS, Costa MSSP, Amorim MOR, et al. (2018) Anti-Thrombin, Anti-Adhesive, Anti-Migratory, and Anti-Proliferative Activities of Sulfated Galactans from the Tropical Green Seaweed, Udotea flabellum. Mar Drugs 17(1): E5.

423. Jiao G, Yu G, Zhang J, Ewart HS (2011) Chemical structures and bioactivities of sulfated polysaccharides from marine algae. Mar Drugs 9(2): 196-223.
424. Carvalhal F, Cristelo RR, Resende DISP, Pinto MMM, Sousa E, Correia-da-Silva M (2019) Antithrombotics from the Sea: Polysaccharides and Beyond. Mar Drugs 17(3): E170.

425. He X, Zang J, Liao P, Zheng Y, Lu Y, et al. (2019) Distribution and Dietary Predictors of Urinary Phthalate Metabolites among Pregnant Women in Shanghai, China. Int J Environ Res Public Healt 16(8): E1366.

426. Gomes DL, Melo KRT, Queiroz MF, Batista LANC, Santos PC, et al. (2019) In Vitro Studies Reveal Antiurolithic Effect of Antioxidant Sulfated Polysaccharides from the Green Seaweed Caulerpa cupressoides var flabellata. Mar Drug 17(6): E326.

427. Kang JI, Kim SC, Han SC, Hong HJ, Jeon YJ, et al. (2012) Hair-Loss Preventing Effect of Grateloupia elliptica. Biomol Ther (Seoul) 20(1): 118-124.

428. Machado LP, Matsumoto ST, Jamal CM, da Silva MB, Centeno Dda C, et al. (2014) Chemical analysis and toxicity of seaweed extracts with inhibitory activity against tropical fruit anthracnose fungi. J Sci Food Agric 94(9): 1739-1744.

429. El Amrani Zerrifi S, Tazart Z, El Khalloufi F, Oudra B, Campos A, et al. (2019) Potential control of toxic cyanobacteria blooms with Moroccan seaweed extracts. Environ Sci Pollut Res Int 26(15): 1521815228. 